$10-1-2013$

\title{
Reclaiming the Equitable Heritage of Habeas
}

Erica J. Hashimoto

University of Georgia, hashimo@uga.edu

D bepress

\section{Repository Citation}

Erica J. Hashimoto, Reclaiming the Equitable Heritage of Habeas, 108 Nw. U. L. Rev. 139 (2013),

Available at: https://digitalcommons.law.uga.edu/fac_artchop/1001

This Article is brought to you for free and open access by the Faculty Scholarship at Digital Commons @ University of Georgia School of Law. It has been accepted for inclusion in Scholarly Works by an authorized administrator of Digital Commons @ University of Georgia School of Law. Please share how you have benefited from this access For more information, please contact tstriepe@uga.edu. 


\title{
RECLAIMING THE EQUITABLE HERITAGE OF HABEAS
}

\section{Erica Hashimoto}

\begin{abstract}
Equity runs through the law of habeas corpus. Throughout the seventeenth and eighteenth centuries, prisoners in England sought the Great Writ primarily from a common law court - the Court of King's Bench-but that court's exercise of power to issue the writ was built around equitable principles. Against this backdrop, it is hardly surprising that modern-day habeas law draws deeply on traditional equitable considerations. Criticism of current habeas doctrine centers on the risk that its rules - and particularly the five gatekeeping doctrines that preclude consideration of claims - produce unfair results. But in fact, four of these five bars exhibit significant equitable characteristics. The sole outlier, the Supreme Court's retroactivity bar, strictly prohibits relief when an applicant relies on a new rule of constitutional procedure, without regard to the blamelessness of the applicant's conduct or the nature of the claim.

The nonequitable nature of the retroactivity bar causes both individual and institutional harms. Of particular importance, because it operates irrespective of how compelling the individual claim of error may be, it blocks the opportunity to secure relief on claims in approximately one quarter of all capital habeas cases. The nonretroactivity rule also makes it impossible for courts to recognize new rights applicable to collateral proceedings, no matter how sound such new rights might be.

This Article argues that the Supreme Court should modify its retroactivity doctrine to reflect equity's traditions. In particular, the Court should adopt three individualized equitable exceptions to the now-absolute retroactivity bar that take account of applicants' conduct in pursuing claims, the merits of the claims and the stakes involved, and the unavailability of alternative remedies. These exceptions might not alleviate all of the inequities created by the nonretroactivity rule. They would, however, bring it more in line with its four companion habeas bars, providing a measure of coherence to these gatekeeping doctrines and reconnecting the nonretroactivity rule with the writ's deep equitable roots.
\end{abstract}

AUTHOR-Associate Professor, University of Georgia School of Law. I greatly appreciate the comments provided by Dan Coenen and Stephen Vladeck. I also want to thank my research assistants Lennon Haas ('12), Matthew Onyett ('13), and Ryan Tuck ('12) for all of their work. 


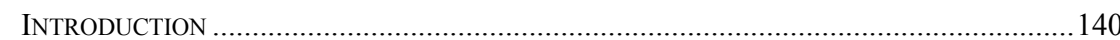

I. The History of Habeas Corpus AND Its GateKeEPing Limitations................. 143

II. The Equitable Roots of (Most of) the Habeas Bars ...................................... 150

A. Habeas Bars and Their Traditional Equitable Corollaries .........................151

B. Focus on the Applicant's Conduct ............................................................ 155

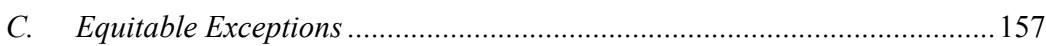

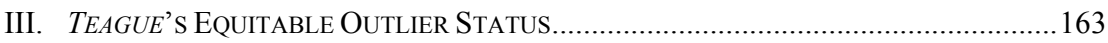

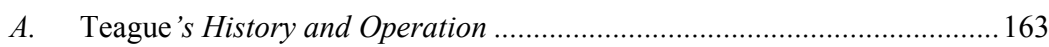

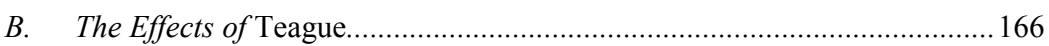

C. The Anomalous and Inequitable Nature of the Teague Rule ....................... 170

IV. EQUITY AND NONRETROACTIVITY REVISITED.......................................................... 172

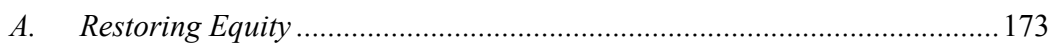

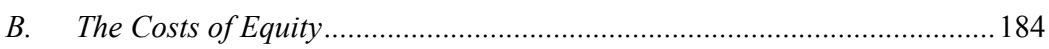

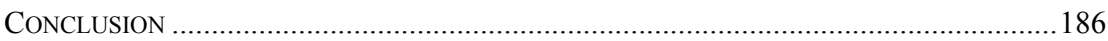

\section{INTRODUCTION}

The post-conviction habeas corpus remedy has long resided in a legal no-man's-land. ${ }^{1}$ It involves rulings about criminal process in the context of a civil proceeding. It empowers lower federal courts to review state court convictions and even state supreme court judgments. ${ }^{2}$ And despite the writ's deep equitable roots, the Supreme Court and Congress in recent decades have curtailed its availability in ways that strike many as inequitable. ${ }^{3}$

Perhaps as a result, the modern doctrine has been described as "an intellectual disaster area" and as having "a Rube Goldberg quality that frustrates all efforts to give it logical coherence." In particular, the Court and Congress have imposed five procedural gatekeeping requirements that, unless the claim falls within a delineated exception, operate as affirmative defenses, completely barring federal courts from reaching the merits of

\footnotetext{
1 This Article focuses almost exclusively on the post-conviction habeas remedy. The Court's recent pre-conviction cases - many of which stem from litigation brought by the detainees at Guantanamo Bay-are discussed only to the extent that they may have affected the Court's analysis in postconviction cases.

${ }^{2}$ Congress has codified the modern statutory habeas rules in the Antiterrorism and Effective Death Penalty Act of 1996 (AEDPA). Pub. L. No. 104-132, §§ 101, 105, 110 Stat. 1214, 1217, 1220 (codified as amended in scattered sections of the U.S. Code).

${ }^{3}$ See, e.g., Bruce Ledewitz, Habeas Corpus as a Safety Valve for Innocence, 18 N.Y.U. REv. L. \& Soc. ChANGe 415, 415, 449 (1991) ("In recent years, a series of United States Supreme Court decisions has restricted access by state prisoners to the Great Writ.").

${ }^{4}$ Larry W. Yackle, The Figure in the Carpet, 78 TEX. L. REV. 1731, 1756 (2000).

5 Joseph L. Hoffmann \& William J. Stuntz, Habeas After the Revolution, 1993 SuP. CT. REV. 65, 109.
} 
habeas claims: (1) a rule that applicants must exhaust their claims in state court, ${ }^{6}(2)$ a procedural default doctrine that generally bars a remedy if the state court ruling rests on an independent state procedural ground, ${ }^{7}$ (3) an abuse of the writ doctrine that precludes relief for most successive petitions, ${ }^{8}$ (4) a time limitations rule that requires prompt filing, ${ }^{9}$ and (5) the Teague rule preventing consideration of claims that rely on "new rules" of constitutional procedure. ${ }^{10}$ As these five companion doctrines have taken hold, scholars have searched in vain for sound overarching principles binding them together. ${ }^{11}$

The Court's most frequently expressed justifications for these bars, intoned almost as a mantra, rest on concerns about comity, federalism, and finality. ${ }^{12}$ But this now-familiar rhetoric fails, in part because virtually any limitation on the habeas remedy (including its complete elimination) would further these aims. No less importantly, the Court has not satisfactorily explained how these concerns are connected to the applicability of the writ. Although the Court has suggested that comity, federalism, and finality are connected with "equitable principles,"13 it has never explained why that is so.

628 U.S.C. $§ 2254$ (b)(1)(A) (2006). This Article uses the term "applicant" to denote the plaintiff in a federal habeas action because the habeas statute uses that term.

7 See, e.g., Martinez v. Ryan, 132 S. Ct. 1309, 1316 (2012) (noting that under the procedural default rules, "a federal court will not review the merits of claims, including constitutional claims, that a state court declined to hear because the prisoner failed to abide by a state procedural rule").

${ }^{8} 28$ U.S.C. $\S 2244(b)$.

${ }^{9}$ Id. $\S 2244(\mathrm{~d})$.

${ }^{10}$ Teague v. Lane, 489 U.S. 288, 310 (1989) (O’Connor, J., plurality opinion).

11 See, e.g., Evan Tsen Lee, The Theories of Federal Habeas Corpus, 72 WASH. U. L.Q. 151, $152-$ 54 (1994) (identifying four potential theories); Yackle, supra note 4 (noting that scholars have advocated varying theories to explain the conceptual foundation for habeas law).

12 See, e.g., Duncan v. Walker, 533 U.S. 167, 178 (2001) (explaining that the purpose of the statutory habeas bars is to "further the principles of comity, finality, and federalism" (quoting Williams v. Taylor, 529 U.S. 420, 436 (2000))); McCleskey v. Zant, 499 U.S. 467, $492-93$ (1991) (noting that comity and federalism concerns shape reticence about requiring the state to defend "second or subsequent habeas proceeding[s] on grounds not even raised in the first petition"); Teague, 489 U.S. at 308-10 (O’Connor, J., plurality opinion) (justifying the nonretroactivity rule by noting that "interests of comity and finality must . . . be considered in determining the proper scope of habeas review"); see also Ann Woolhandler, Demodeling Habeas, 45 StAN. L. REv. 575, 577-79 (1993) (discussing the various theories on the proper scope of the habeas writ and their differing invocation of finality, comity, and federalism interests); Angela Ellis, Note, "Is Innocence Irrelevant" to AEDPA's Statute of Limitations? Avoiding a Miscarriage of Justice in Federal Habeas Corpus, 56 VILL. L. REV. 129, 138 n.48 (2011) ("Commentators generally agree that [the Court's] decisions significantly altered the scope of habeas review in response to concerns for federalism, comity, and finality.").

13 See, e.g., Withrow v. Williams, 507 U.S. 680, 716-17 (1993) (Scalia, J., concurring in part and dissenting in part) (noting that habeas jurisdiction, including the exhaustion and nonretroactivity requirements, "is tempered by the restraints that accompany the exercise of equitable discretion"); McCleskey, 499 U.S. at 493 (noting that both the abuse of the writ and procedural default doctrines "invoke equitable principles to define the court's discretion"). 
In short, the Court's loose talk of comity, federalism, and finality offers a wholly inadequate explanation for the habeas gatekeeping mechanisms it has fashioned. Even worse, it has obscured the importance of habeas's equitable roots to current doctrine. ${ }^{14}$ Indeed, four of the five bars - abuse of the writ, procedural default, exhaustion, and timelinessshare features that correspond with the remedy's historical equitable origins. First, all four adhere to traditional equitable defenses, including unclean hands, laches, and the availability of an adequate remedy at law. Second, each doctrine focuses on the applicant's conduct, taking account of whether delays and failures to raise claims were justifiable or not. Finally, in keeping with traditional equitable notions, the Court has fashioned ameliorative exceptions to each bar that respond to case-specific considerations of fairness. ${ }^{15}$

The Court's Teague retroactivity bar-which eliminates the habeas remedy for the violation of any new constitutional procedural rule recognized after the applicant's conviction became final ${ }^{16}$ - does not share these critical characteristics. It has no connection to any traditional equitable doctrine, it does not respond to any individual blameworthy conduct, and it does not give way based on considerations of individual circumstances, regardless of how compelling they are. Empirical evidence demonstrates that capital cases represent a disproportionate percentage of Teague-barred claims, making the retroactivity bar's absence of any equitable characteristics particularly problematic. ${ }^{17}$ This Article both documents and responds to the nonequitable nature of the Court's current - and distinctively rigid - retroactivity bar. In particular, it urges the Court to refashion its retroactivity bar by drawing on traditional equity practices to create exceptions that take account of individual burdens and blame.

This Article proceeds in four parts. Part I examines the historical equitable ancestry of the habeas remedy and provides an overview of the current habeas doctrine's gatekeeping requirements. Part II analyzes the ways in which four of those gatekeeping limitations draw on the remedy's equitable origins. Part III turns to the Court's nonretroactivity doctrine, its development, and the ways in which it abandons the equitable principles

\footnotetext{
14 The Court frequently has invoked "equitable principles" in its decisions, but virtually all of those references involve only the state's federalism, comity, and finality concerns. See, e.g., McCleskey, 499 U.S. at 492-93; Teague, 489 U.S. at 308-10 (O’Connor, J., plurality opinion); Rose v. Lundy, 455 U.S. 509, 514-16 (1982); Wainwright v. Sykes, 433 U.S. 72, 80-82 (1977).

15 See, e.g., Coleman v. Thompson, 501 U.S. 722, 750 (1991); McCleskey, 499 U.S. at $493-94$.

16 Teague, 489 U.S. at 310 (O’Connor, J., plurality opinion).

17 See Nancy J. King, Fred L. CheEsman II \& Brian J. Ostrom, Final TeChnical Report: HABEAS Litigation IN U.S. District COURTS 45, 49 (2007), available at https://www.ncjrs.gov/ pdffiles1/nij/grants/219559.pdf (setting forth data demonstrating that almost $24 \%$ of capital habeas cases had at least one Teague-barred claim, while less than $1 \%$ of the noncapital claims had a Teaguebarred claim).
} 
present in the other gatekeeping limitations. Finally, Part IV offers concrete proposals that would enable the Court to introduce equity into the retroactivity bar.

\section{THE HISTORY OF HABEAS CORPUS AND ITS GATEKEEPING LIMITATIONS}

The Judiciary Act of 1789 provided an equitable remedy to prisoners "in custody, under or by colour of the authority of the United States." ${ }^{18}$ In keeping with English common law, the Court held that the statute authorized relief from confinement where the court imposing confinement lacked jurisdiction or where the Executive had detained the prisoner without legal process. ${ }^{19}$ Over the next 150 years, Congress and the Supreme Court expanded the scope of the habeas remedy in two major ways. First, in 1867, Congress authorized federal courts to grant writs of habeas corpus to prisoners in state (as well as federal) custody. ${ }^{20}$ Second, the Court held that a federal writ of habeas corpus could be granted to any prisoner claiming that a court in an earlier criminal proceeding had disregarded his constitutional rights and that "the writ is the only effective means of preserving his rights." 21

These substantive expansions were consistent with the historically broad, equitable nature of the writ - both in England and in the United States. Professor Paul Halliday's careful historical account of the use of habeas corpus by the King's Bench in England demonstrates that, although the King's Bench was a common law court, it used habeas in a way that "was equitable in everything but name." 22 In particular, the King's Bench could "plug any existing gaps in law to right all wrongs." ${ }^{23}$ The habeas

\footnotetext{
${ }^{18}$ Ch. $20, \S 14,1$ Stat. $73,81-82$. As other scholars have noted, the federal statutory habeas remedy merely supplemented the common law habeas remedy available in state courts, and even post-Erie, the federal courts also for many years created a federal "common law" of habeas. See, e.g., ERIC M. FREEDMAN, HABEAS CORPUS: RETHINKING THE GREAT WRIT OF LIBERTY (2001); Stephen I. Vladeck, Common-Law Habeas and the Separation of Powers, 95 Iowa L. Rev. Bull. 39, $43-47$ (2010). As discussed below, many of the federal habeas gatekeeping bars initially arose as part of that common law tradition.

${ }^{19}$ E.g., McCleskey, 499 U.S. at 478; Paul M. Bator, Finality in Criminal Law and Federal Habeas Corpus for State Prisoners, 76 HARV. L. REV. 441, 487 n.120 (1963); James S. Liebman, Apocalypse Next Time?: The Anachronistic Attack on Habeas Corpus/Direct Review Parity, 92 Colum. L. Rev. 1997, 2041-42 (1992); Emily Garcia Uhrig, A Case for a Constitutional Right to Counsel in Habeas Corpus, 60 HASTINGS L.J. 541, 575 (2009).

${ }^{20}$ Act of Feb. 5, 1867, ch. 28, § 1, 14 Stat. 385; see also McCleskey, 499 U.S. at 478 (discussing the statutory and judicial forces that expanded the scope of the writ).

${ }^{21}$ Waley v. Johnston, 316 U.S. 101, 104-05 (1942) (per curiam). This Article uses the male pronoun for habeas applicants because the overwhelming majority of applicants in federal court are male. See KING ET AL., supra note 17, at 19 (concluding that $3.8 \%$ of noncapital applicants and $1.1 \%$ of capital applicants in the sample were women).

22 Paul D. Halliday, Habeas Corpus: From England to Empire 87 (2010).

${ }^{23} I d$.
} 
remedy also took account of petitioners' individual circumstances, "rather than imposing obedience to a set of rules inscribed in precedents." ${ }^{24}$ This flexibility of the King's Bench habeas remedy, and its sensitivity to the particular facts of the petitioner's case, demonstrated the equitable nature of the remedy. ${ }^{25}$

Professor Halliday's research highlights several features about the issuance of the writs. First, and perhaps most important, "was the central fact of habeas corpus: that a judge should hear the sighs of all prisoners, regardless of where, how, or by whom they were held." ${ }^{26}$ Second, the justices of the King's Bench freely used the common law writ to review imprisonment, even after Parliament passed the 1679 Habeas Corpus Act. ${ }^{27}$ As a result, the writ continued to evolve as an instrument fine-tuned by judges and largely uninfluenced by parliamentary intervention. Finally, the power of the King's Bench to issue the writ emanated from the King's prerogative - the highly discretionary power the King wielded over his subjects - rather than from entrenched ideas about particular protections of individual liberty. ${ }^{28}$ All of those to whom the King delegated power held the King's prerogative- " $[w]$ hether a sheriff or common jailer, a tipstaff or messenger, whoever held the custody of one of the [K]ing's subjects did so by the prerogative. ${ }^{29}$ Given their distinctly close relation to the King ${ }^{30}$ the King's Bench justices had the prerogative to inspect the work of all others to whom the King had delegated authority to imprison.

Use of the habeas remedy by the King's Bench peaked in $1789,{ }^{31}$ a significant fact because the Court has made clear that the protection of the writ in 1789 represents the "absolute minimum" for the current writ's protection under the Suspension Clause. ${ }^{32}$ In the years leading up to 1789, the justices of the King's Bench increasingly used common law writs of habeas corpus to assert their authority to review imprisonment and release those unlawfully detained. ${ }^{33}$ To be sure, many of those released had been imprisoned prior to conviction, but particularly in the early 17 th century, a

\footnotetext{
24 Id. at 102.

$25 \mathrm{Id}$.

${ }^{26} I d$. at 7 (emphasis added).

27 Id. at 239; Stephen I. Vladeck, The New Habeas Revisionism, 124 HARV. L. REV. 941, 953-57 (2011) (book review).

${ }^{28}$ HALliDAY, supra note 22, at 7, 75 .

${ }^{29}$ Id. at 74 .

${ }^{30} I d$. at 75 (describing the close proximity of the King's Bench justices to the King, both "legally as well as literally").

31 Id. at 314; see also Vladeck, supra note 27, at 957-58 (characterizing 1777 to 1789 as "the highwater mark of habeas in England"). Professor Halliday's book draws from his review of every habeas corpus ad subjiciendum writ issued from the King's Bench every fourth year from 1502-1798. HALLIDAY, supra note 22, app. at 319.

32 INS v. St. Cyr, 533 U.S. 289, 301 (2001).

33 HALLIDAY, supra note 22, at 309-10.
} 
significant percentage of the writs were issued post-conviction. ${ }^{34}$ In short, Professor Halliday's historical account makes clear that the habeas writ in England was rooted in equitable principles, used broadly, and marked by flexibility rather than rigid and restrictive rules. ${ }^{35}$

As the substantive reach of the habeas remedy expanded in the United States, however, the Supreme Court and then Congress set forth a series of procedural limitations - in particular, five gatekeeping requirements - that prevent federal courts from reaching the merits of habeas claims. The Court and Congress clearly have the authority to adopt such limitations. Congress determines the contours of the habeas remedy, and therefore can procedurally limit access to it, ${ }^{36}$ and the Court for many years has exercised broad discretion in fashioning the remedy as part of its authority to interpret the habeas statute, crafting limitations on its availability even where it has jurisdiction. ${ }^{37}$ Less clear is whether the gatekeeping requirements that Congress and the Court have developed make a coherent and justifiable body of doctrine.

Before turning to that matter, a brief description of each of the five gatekeeping requirements is in order. The five bars mandate dismissal of habeas claims ${ }^{38}$ for: (1) failure to exhaust state remedies, (2) procedural default of an issue before the state court, (3) abuse of the writ through second or successive petitions, (4) failure to timely file, and (5) nonretroactivity. There are additional provisions limiting the availability of the habeas remedy, including AEDPA's requirement of deference to state court findings, ${ }^{39}$ and the version of the harmless error

\footnotetext{
${ }^{34} I$ d. app. at 328 ("When summary convictions are included in the analysis-the means by which most misdemeanants were convicted - post-conviction writs peaked in the early to middle part of the seventeenth century, as overall use of habeas corpus for misdemeanors peaked. For the period 16001650 , nearly one-third (31\%) of writs issued after conviction.").

${ }^{35} I d$. at $100-01$.

${ }^{36}$ See, e.g., Brown v. Allen, 344 U.S. 443, 508-10 (1953) (deferring to Congress's authority to determine the availability of habeas relief). Of course, Congress's power to shape the writ is cabined by the Constitution's prohibition on suspending the writ. U.S. CONST. art. I, § 9, cl. 2; see also Felker v. Turpin, 518 U.S. 651, 654, 656 (1996) (holding that AEDPA's limitations on second or successive petitions do not violate the Suspension Clause); Kent S. Sheidegger, Habeas Corpus, Relitigation, and the Legislative Power, 98 CoLUM. L. REV. 888, 932 (1998) (noting the Court's power to strike down congressional enactments that violate the Suspension Clause).

37 See Danforth v. Minnesota, 552 U.S. 264, 278 (2008) (noting that the nonretroactivity rule from Teague v. Lane, 489 U.S. 288, 308-10 (1989) (O'Connor, J., plurality opinion), is "an exercise of this Court's power to interpret the federal habeas statute"); Teague, 489 U.S. at 308 (O'Connor, J., plurality opinion) (situating the nonretroactivity rule within the corpus of the Court-created habeas rules designed to preserve comity and finality); Wainwright v. Sykes, 433 U.S. 72, 85-91 (1977) (declining to grant habeas relief because of the equitable and prudential considerations implicated by procedural default).

${ }^{38}$ Each of the bars (with the possible exception of the Teague bar) permits consideration of claims under certain circumstances. See infra Parts II.C, III.C.

39 See 28 U.S.C. $\$ 2254(d)(1)-(2)$ (2006).
} 
standard that governs habeas relief for constitutional error. ${ }^{40}$ But those are categorically different from the gatekeeping requirements in that they do not altogether bar the courts from reaching the merits of habeas claims; instead, they simply set forth standards for considering those claims. Accordingly, the scope of this Article is limited to the five gatekeeping requirements.

The history of the first requirement, that applicants first exhaust their remedies in state court, dates back at least to Ex Parte Royall in $1886 .^{41}$ The Court justified this requirement on the grounds that it protects "the state courts" role in the enforcement of federal law"42 and that it ensures the development of a more complete record before applicants present their claims in federal court. ${ }^{43}$ Congress later codified this requirement so that a habeas writ "shall not be granted unless ... the applicant has exhausted the remedies available in the courts of the State," or unless the state either lacks any corrective process or the process is "ineffective to protect the rights of the applicant." 44 The statute also specifies that "[a]n applicant shall not be deemed to have exhausted the remedies available in the courts of the State ... if he has the right under law of the State to raise, by any available procedure, the question presented," ${ }^{45}$ thereby assuring that federal courts cannot reach claims where a state remedy is available.

Under the second bar-the procedural default doctrine-if an applicant fails to comply with a state's procedural rules and the state court therefore does not decide the merits of his claims, a federal habeas court cannot reach the merits of those claims ${ }^{46}$ For instance, if an applicant did not comply with a state's contemporaneous objection rule ${ }^{47}$ or its time limitations for filing appeals, ${ }^{48}$ and the state court, relying on its own rules, refused to consider the merits of the claims he raises on habeas, the federal

\footnotetext{
${ }^{40}$ See Brecht v. Abrahamson, 507 U.S. 619, 623 (1993) (holding that the standard on habeas is whether the constitutional error had "substantial and injurious effect or influence in determining the jury's verdict," rather than whether it was harmless beyond a reasonable doubt (quoting Kotteakos v. United States, 328 U.S. 750, $776(1946))$ ).

${ }^{41}$ See 117 U.S. 241, 250-52 (1886).

42 Rose v. Lundy, 455 U.S. 509,518 (1982).

${ }^{43} I d$. at 519 .

4428 U.S.C. $\S 2254($ b)(1).

45 Id. § 2254(c).

${ }^{46}$ See, e.g., Martinez v. Ryan, 132 S. Ct. 1309, 1316 (2012) (noting that, under the procedural default rules, "a federal court will not review the merits of claims, including constitutional claims, that a state court declined to hear because the prisoner failed to abide by a state procedural rule"); Coleman v. Thompson, 501 U.S. 722, 747-48, 750 (1991) (noting that a court will not hear a claim defaulted under state procedural rules absent cause and actual prejudice or a finding that "failure to consider the claims will result in a fundamental miscarriage of justice").

47 See, e.g., Wainwright v. Sykes, 433 U.S. 72, 91 (1977) (refusing to grant habeas relief because the petitioner's failure to timely object under the state's contemporaneous objection rule barred federal review).

48 See, e.g., Coleman, 501 U.S. at 750-51, 757 (barring habeas claim).
} 
habeas court cannot reach the merits of those claims. ${ }^{49}$ Unlike several of the other habeas bars, Congress has never codified the procedural default rule.

Third, the abuse of the writ doctrine bars federal habeas courts from considering claims raised in second or successive habeas petitions. Although the Court has rejected a strict res judicata rule to bar claims that were or might have been asserted in a previous petition, ${ }^{50}$ it has imposed res judicata-like limits on petitioners by way of this doctrine. ${ }^{51}$ The Court first explicitly recognized this rule in $1924 .{ }^{52}$ Congress then codified it in $1948,{ }^{53}$ and expanded the limits on filing successive petitions when it passed AEDPA in $1996 .{ }^{54}$

Fourth, AEDPA imposes a one-year filing deadline on habeas claims. ${ }^{55}$ Not surprisingly, the Court had not previously adopted a statute of limitations for habeas actions. ${ }^{56}$ Even so, AEDPA's limitation built on a rule that permitted courts to dismiss petitions for unreasonable delay if it appeared that the State was "prejudiced in its ability to respond to the petition by delay in its filing." 57

Finally, the retroactivity rule announced in Teague $v$. Lane prohibits habeas courts from applying any new constitutional criminal procedure rule

49 As discussed below, there is an exception if the applicant can establish "cause" for the default and "prejudice" from the failure to consider his claims. See infra Part II.C.

50 See Brown v. Allen, 344 U.S. 443, 458 (1953).

51 See McCleskey v. Zant, 499 U.S. 467, 480-82 (1991) (distinguishing the doctrine from res judicata); Wong Doo v. United States, 265 U.S. 239, 241 (1924) (upholding dismissal of habeas petition because the applicant already had litigated the issue and been denied relief).

52 See, e.g., Salinger v. Loisel, 265 U.S. 224, 230-32 (1924); Wong Doo, 265 U.S. at 241.

5328 U.S.C. $\S 2244$ (1948) (providing that federal courts need not entertain successive petitions if "the petition presents no new ground not theretofore presented and determined, and the judge or court is satisfied that the ends of justice will not be served by such an inquiry"); Karen C. Lapidus, Note, Rose v. Lundy and Rule 9(b): Will the Court Abuse the Great Writ?, 49 BroOK. L. REV. 335, 352 n.106 (1983).

5428 U.S.C. $\S 2244($ b), amended by AEDPA, Pub. L. No. 104-132, § 106, 110 Stat. 1214, 1220-21 (1996). AEDPA amendments set forth an elaborate gatekeeping mechanism for determining whether a successive petition should be barred or falls within one of the exceptions. An applicant filing a second or successive petition must first file a motion in the court of appeals for an order authorizing the district court to consider the petition, which requires the applicant to make a "prima facie showing" that the petition falls within one of the exceptions. Id. $\$ 2244(\mathrm{~b})(3)(\mathrm{C})$. Even if the court of appeals authorizes the district court to consider the petition, moreover, the district court has an independent obligation to ensure that "the claim satisfies the requirements" related to second and successive petitions. Id. $\S 2244(\mathrm{~b})(4)$.

55 Id. $\S 2244(\mathrm{~d})$, amended by AEDPA $\S \S 101,110$. The one-year period generally begins when the conviction becomes final and excludes any time during which a "properly filed application for State post-conviction or other collateral review ... is pending," although the statute also lists several other narrow circumstances that can trigger a later start to the limitations period. Id.

56 Day v. McDonough, 547 U.S. 198, 202 n.1 (2006).

57 See Rules Governing SECtion 2254 CASES IN THE United States District Courts § 9(a) (1977); Day, 547 U.S. at 214-15 (Scalia, J., dissenting) (noting that prior to the 1977 adoption of the unreasonable delay rule, "lower courts regularly entertained petitions filed after even extraordinary delays" such as twenty-four, thirty-six, and forty years). 
if the applicant's conviction had become final before the Court announced that "new rule." 58 The Court observed that "[i]t is admittedly often difficult to determine when a case announces a new rule," 59 but it has gone on to give the "new rule" label a broad reach, declaring it applicable so long as the rule was "susceptible to debate among reasonable minds" when the Court issued its opinion..$^{60}$ Like the procedural default rule (and unlike the exhaustion and abuse of the writ doctrines), Congress has not expressly codified the Teague doctrine. ${ }^{61}$

In justifying each of these five limitations on the scope of the habeas writ, the Court-and sometimes Congress as well-has emphasized the importance of "equitable principles." ${ }^{2}$ But instead of invoking traditional equitable concepts such as laches or unclean hands, the Court has rested its rules on the basis of three "prudential concerns"-comity, federalism, and interests in finality. ${ }^{63}$

The Court's rote invocation of these interests ultimately is unsatisfactory for two related reasons. As an initial matter, a desire to promote interests in comity, federalism, and finality cannot suffice to justify these specific limitations since every rule limiting the availability of

58489 U.S. 288, 310 (1989) (O’Connor, J., plurality opinion).

59 Id. at 301; see also Linda Meyer, "Nothing We Say Matters": Teague and New Rules, 61 U. CHI. L. REV. 423, 438-47, 459-60 (1994) (criticizing the Court's broad and unwieldy definition of new rules).

${ }^{60}$ Butler v. McKellar, 494 U.S. 407, 415 (1990). The Court also observed that lower court disagreement on the issue could demonstrate the rule's newness. Id.

${ }^{61}$ See Greene v. Fisher, 132 S. Ct. 38, 44 (2011) (internal quotation marks omitted) (noting that "AEDPA did not codify Teague, and ... the AEDPA and Teague inquiries are distinct"); Larry W. Yackle, A Primer on the New Habeas Corpus Statute, 44 BufF. L. Rev. 381, 416 (1996) (arguing that 28 U.S.C. $\$ 2254$ (d) "does not incorporate the Supreme Court's Teague doctrine in so many words, despite available illustrations of how that might be done"). But see generally Note, Rewriting the Great Writ: Standards of Review for Habeas Corpus Under the New 28 U.S.C. $\$ 2254,110$ HARV. L. REV. $1868,1882-85$ (1997) (reading 28 U.S.C. § 2254(d) as "track[ing] the general rule of Teague, albeit in a somewhat roundabout way" and interpreting §2254(d)(1) as codifying at least one of the Teague exceptions).

62 See, e.g., Withrow v. Williams, 507 U.S. 680, 716-17 (1993) (Scalia, J., concurring in part and dissenting in part) (noting that habeas jurisdiction, including the exhaustion and nonretroactivity requirements, "is tempered by the restraints that accompany the exercise of equitable discretion"); McCleskey v. Zant, 499 U.S. 467, 493 (1991) (noting that both the abuse of the writ and procedural default doctrines "invoke equitable principles to define the court's discretion").

${ }^{63}$ See, e.g., McCleskey, 499 U.S. at 492-93 (noting that comity, finality, and federalism concerns shape reticence about "second or subsequent habeas proceeding[s] on grounds not even raised in the first petition"); Teague, 489 U.S. at 308-10 (O'Connor, J., plurality opinion) (justifying the nonretroactivity rule by noting that "interests of comity and finality must... be considered in determining the proper scope of habeas review"); Rose v. Lundy, 455 U.S. 509, 514-16 (1982) (noting finality and comity arguments for exhaustion doctrine); Wainwright v. Sykes, 433 U.S. 72, 80-82 (1977) (noting federalism and comity arguments for procedural default doctrine). As discussed below, the Court recently has invoked traditional equitable principles in its decisions, but that is only a very recent development. See infra note 69 and accompanying text. 
habeas relief will promote those interests. ${ }^{64}$ For example, a state could ask the Court, in the exercise of its equitable discretion, to adopt a new gatekeeping rule that conditions access to habeas on an applicant's obtaining certification from the state that his claims have merit. Such a rule would greatly promote the state's interests in comity, federalism, and finality. By severely curtailing the federal habeas remedy, it would promote finality, and it would promote federalism and comity by respecting the state's own assessment of the merits of applicants' claims. Indeed, eliminating the federal habeas remedy altogether for those convicted in state courts would most fully protect these three state interests. As a result, the gatekeeping mechanisms described above cannot be justified simply on the grounds that they further these state interests.

Second, justifying these limitations based on state interests in comity, federalism, and finality fails to honor the habeas writ's deep equitable roots. Although values of comity, federalism, and finality might carry weight in an equitable balance, ${ }^{65}$ they cannot stand alone. Even more important, these considerations stray from the core equitable principle that "equity will not suffer a wrong without a remedy." ${ }^{66}$ Put simply, comity, federalism, and finality at most may constitute interests for habeas courts to

\footnotetext{
${ }^{64}$ See, e.g., McCleskey, 499 U.S. at 491 (noting that the writ "strikes at finality"); Coleman v. Thompson, 501 U.S. 722, 748 (1991) (citations and internal quotation marks omitted) ("[T]he Great Writ entails significant costs[,] [t]he most significant of [which] is the cost to finality ...."); Engle v. Isaac, 456 U.S. 107, 127 (1982) ("[T]he writ undermines the usual principles of finality of litigation.”); Mackey v. United States, 401 U.S. 667, 690-92 (1971) (Harlan, J., concurring in part and dissenting in part) (decrying the destruction of finality wrought by habeas writs).

${ }^{65}$ Scholars recently have pointed to the dearth of any evidence that courts prior to the midnineteenth century "balanced" the equities before awarding equitable relief. See Peter ChARLES HofFer, The LAW's Conscience: EQuitable Constitutionalism in AMERiCA 152 (1990) (concluding that the first American equitable balancing case was decided in 1868); Jared A. Goldstein, Equitable Balancing in the Age of Statutes, 96 VA. L. REv. 485, 492 (2010) ("English and American courts in the seventeenth, eighteenth, and early nineteenth centuries neither spoke of balancing the equities nor employed a balancing approach in deciding whether to grant injunctions."). Instead, prior to 1868 , courts appear to have ordered equitable relief only where the petitioner had a meritorious case and none of the traditional equitable reasons for denying relief-such as unclean hands, availability of relief at law, laches, or estoppel—applied. Id. at 492-93.

More modern cases, however, suggest that equitable courts should balance the interests of the parties in determining whether to grant relief. See, e.g., Lemon v. Kurtzman, 411 U.S. 192, 201 (1973) ("In equity, as nowhere else, courts eschew rigid absolutes and look to the practical realities and necessities inescapably involved in reconciling competing interests ....").

${ }^{66}$ E.g., Key Corporate Capital, Inc. v. Cnty. of Beaufort, 602 S.E.2d 104, 107 (S.C. Ct. App. 2004) (quoting Lane v. N.Y. Life Ins. Co., 145 S.E. 196, 207 (S.C. 1928)); Unity Tel. Co. v. Design Serv. Co. of N.Y., 179 A.2d 804, 811 (Me. 1962); Lane, 145 S.E. at 207. Of course, to order relief equity courts needed to have jurisdiction, and the remedy traditionally was subject to certain defenses. First State Bank of Clermont v. Fitch, 141 So. 299, 301 (Fla. 1932) (characterizing that maxim as "necessarily subordinate to positive principles" and noting that it "cannot be applied either to subvert established rules of law or to give the courts a jurisdiction hitherto unknown"). But comity and federalism considerations never lay at the heart of equity.
} 
consider, but they cannot alone justify mechanical rules barring access to the equitable remedy.

\section{The Equitable RoOTS OF (MOST OF) THE HABEAS BARS}

The Supreme Court's rote invocation of comity, finality, and federalism to justify the gatekeeping limitations on the writ of habeas corpus does not reflect the equitable roots of the habeas doctrine. In practice, though, most of these limitations reflect attentiveness to equitable principles. ${ }^{67}$ In fact, traditional equitable principles have shaped those limitations and the resulting scope of the writ. ${ }^{68}$ For this reason, much of the doctrine not only is coherent but also historically well-grounded. Indeed, perhaps because of the Court's recognition of equitable principles in pre-conviction cases, the Court very recently has begun recognizing traditional equitable doctrines to justify its decisions in post-conviction cases. $^{69}$

In particular, four of the five gatekeeping bars-exhaustion, procedural default, abuse of the writ, and the statute of limitations in AEDPA - share three characteristics demonstrating their equitable origins. First, each of these four limitations builds on traditional equitable defenses recognized in many fields of law. Second, in keeping with equitable traditions, each of these limitations focuses on the applicant's conduct. Finally, each has individualized exceptions based on equitable considerations. On each of these counts, Teague's nonretroactivity doctrine stands strikingly alone. This is best explained by taking a close look at the four other gatekeeping bars with which the Teague rule contrasts.

${ }^{67}$ Of course, the Court has made clear that despite its equitable roots, the habeas remedy still is governed by a "body of statutes, rules, and precedents." Lonchar v. Thomas, 517 U.S. 314, 323 (1996).

${ }^{68}$ See, e.g., Martinez v. Ryan, 132 S. Ct. 1309, 1318 (2012) (noting that the procedural default rules reflect equitable principles); Holland v. Florida, 130 S. Ct. 2549, 2560 (2010) (internal quotation marks omitted) (noting that "equitable principles have traditionally governed the substantive law of habeas corpus"); Schlup v. Delo, 513 U.S. 298, 319 (1995) ("[H]abeas corpus is, at its core, an equitable remedy."); McCleskey, 499 U.S. at 489 (noting that the abuse of the writ doctrine "refers to a complex and evolving body of equitable principles informed and controlled by historical usage, statutory developments, and judicial decisions"); Kuhlmann v. Wilson, 477 U.S. 436, 451 (1986) (Powell, J., plurality opinion) (rejecting "that federal courts no longer must consider the "ends of justice' before dismissing a successive petition"); Sanders v. United States, 373 U.S. 1, 15-17 (1963) (holding that a habeas court must adjudicate even a successive petition when required to do so by the "ends of justice").

${ }^{69}$ See Martinez, 132 S. Ct. at 1318 (noting the equitable origins of the procedural default doctrine); Holland, $130 \mathrm{~S}$. Ct. at 2562 (holding that equitable tolling applies to AEDPA's statute of limitations because it was hesitant to interpret "AEDPA's statutory silence as indicating a congressional intent to close courthouse doors that a strong equitable claim would ordinarily keep open"). 


\section{A. Habeas Bars and Their Traditional Equitable Corollaries}

Exhaustion, procedural default, abuse of the writ, and the time-based limitation share a common trait: each parallels traditional equitable defenses. The rationale behind the exhaustion doctrine mirrors the traditional withholding of equitable relief when an applicant has an "adequate remedy at law." The procedural default doctrine similarly tracks the traditional equitable unclean hands defense. The rationale for the abuse of the writ doctrine is the same as for res judicata, a defense applied by courts of equity that is rooted in both efficiency and fairness. Finally, even the statute of limitations enacted by Congress has an equitable corollary in the long-honored equitable doctrine of laches.

1. Exhaustion.-The early habeas exhaustion cases framed the requirement that claims first be presented to the state court in terms of the availability of an alternative remedy. ${ }^{70}$ This rationale essentially tracks the traditional defense of withholding equitable relief if an applicant has an available remedy at law. ${ }^{71}$ The "available remedy at law" defense developed from the exceptional nature of equitable relief. ${ }^{72}$ Thus, if an equitable plaintiff had a remedy at law adequate to redress the injury, the equitable court would stay its hand and withhold the extraordinary equitable remedy on the theory that law goes first. ${ }^{73}$ This withholding of relief, moreover, applied whether or not the alternative remedy existed under state or federal law. ${ }^{74}$ And it operated with particular force when the applicant sought to restrain state action. ${ }^{75}$

\footnotetext{
${ }^{70}$ See, e.g., Mooney v. Holohan, 294 U.S. 103, 115 (1935) (per curiam) (holding that before the federal habeas remedy is available, state prisoner applicants must show that they invoked the state's corrective judicial process but it was unavailable); Whitten v. Tomlinson, 160 U.S. 231, 235, 247 (1895) (declining to grant habeas relief in advance of available state proceedings to test the validity of detention); Cook v. Hart, 146 U.S. 183, 194 (1892) ("As the defence in this case is ... equally available in the State as in the Federal courts, we do not feel called upon at this time to consider it ....").

71 See, e.g., Morales v. Trans World Airlines, Inc., 504 U.S. 374, 381 (1992) (internal quotation marks omitted) ("It is a basic doctrine of equity jurisprudence that courts of equity should not act ... when the moving party has an adequate remedy at law ....").

72 See, e.g., Gulf Oil Corp. v. Gilbert, 330 U.S. 501, 513-14 (1947) (Black, J., dissenting) (noting that equity courts generally withheld extraordinary equitable remedies unless common law courts "provided no adequate remedy for an injured person"), superseded in part by statute, 28 U.S.C. $\S 1404$ (a) (1982); Matthews v. Rodgers, 284 U.S. 521, 525 (1932) (noting the longstanding equitable rule that prohibited "recourse to the extraordinary remedies of equity where the right asserted may be fully protected at law").

73 See, e.g., Great Lakes Dredge \& Dock Co. v. Huffman, 319 U.S. 293, 297 (1943).

74 See, e.g., Matthews, 284 U.S. at 526 ("If the remedy at law is plain, adequate, and complete, the aggrieved party is left to that remedy in the state courts... or to his suit at law in the federal courts ....").

75 This was particularly true in cases where the applicant sought to enjoin a state from collecting state taxes. See, e.g., Great Lakes Dredge \& Dock Co., 319 U.S. at 297 ("This Court has recognized that the federal courts, in the exercise of the sound discretion which has traditionally guided courts of equity
} 
The habeas exhaustion requirement mirrors many of those equitable considerations. After all, the courts in forty-nine states provide relief on appeal to criminal defendants whose federal constitutional rights have been abridged. ${ }^{76}$ Requiring a habeas applicant to first seek available relief from state courts prevents federal courts from restraining state action where there is another available remedy. ${ }^{77}$ In addition, it reserves the extraordinary equitable remedy for those cases in which the applicant's actions demonstrate that he has no state remedy. ${ }^{78}$

2. Procedural Default. - In similar fashion, the procedural default doctrine bears a kinship to the traditional equitable defense of unclean hands. Although the origins and precise scope of the unclean hands doctrine have been disputed, ${ }^{79}$ one pithy summary proclaims: "He that hath committed iniquity shall not have equity." 80 Or, to put the same point no less poetically, the doctrine precludes a plaintiff from obtaining equitable relief where he "has soiled his hands by wronging . . the opposite party." 81 In sum, an applicant cannot obtain equitable relief if he has committed a legal wrong related to the dispute that has harmed the defendant. ${ }^{82}$

in granting or withholding the extraordinary relief which they may afford, will not ordinarily restrain state officers from collecting state taxes where state law affords an adequate remedy to the taxpayer.").

${ }^{76}$ See Cassandra Burke Robertson, The Right to Appeal, 91 N.C. L. Rev. 1219, 1222 n.8 (2013) (noting that forty-seven states provide an appellate remedy in all felony cases either by statute or under the Constitution and two other states provide a right to review through court rule). Virginia is the only state that does not provide a right to appeal. See id.

77 The Court has defined "available remedy" for purposes of the exhaustion doctrine as a state remedy that is still available at the time the applicant files his federal petition. See, e.g., Engle v. Isaac, 456 U.S. 107, $125 \mathrm{n} .28$ (1982) (noting that the availability of the remedy for exhaustion purposes depends on its availability "at the time of the federal petition"); Humphrey v. Cady, 405 U.S. 504, 516 (1972) (same); Larry W. Yackle, The Exhaustion Doctrine in Federal Habeas Corpus: An Argument for a Return to First Principles, 44 OHIO ST. L.J. 393, 393 n.2 (1983) ("State remedies that were available at one time, but for some reason are no longer accessible... are relevant not to the question of exhaustion but to the related matter of effect to be given abortive state proceedings.")

${ }^{78}$ Of course, as discussed supra Part I, just because the applicant has no available remedy in state court does not mean that he is entitled to have federal courts consider his habeas claim on the merits. In particular, if the applicant has no available remedy in state court because he has not complied with the state's procedural rules, the procedural default doctrine would bar courts from considering his claim on the merits. See Coleman v. Thompson, 501 U.S. 722, 729-30 (1991) (“[T]he independent and adequate state ground doctrine... applies to bar federal habeas when a state court decline[s] to address a prisoner's federal claims because the prisoner... fail[s] to meet a state procedural requirement."); Wainwright v. Sykes, 433 U.S. 72, 86-87 (1977) (holding that the state procedural default doctrine barred federal habeas review absent a showing of cause and prejudice for the default).

${ }^{79}$ See generally Zechariah Chafee, Jr., Coming Into Equity with Clean Hands, 47 MicH. L. REv. 877,878 (1949) (arguing that the defense neither has a vintage as long as previously thought nor is limited to equitable suits).

${ }^{80}$ See id. at 880 (quoting Richard Francis, MAXIMS OF EQUiTY 5 (London, Henry Lintot, 3d ed. 1746)).

${ }^{81} I d$. at 881 .

82 See id. 
The shadow of unclean hands hangs over the procedural default doctrine. In this context, it is important to remember that the habeas applicant brings a federal action against the State alleging that his continued detention violates his federal constitutional rights. ${ }^{83}$ If the applicant has not complied with the process set forth by the state to review his claims, he has deprived the state court of the opportunity to consider them and to terminate his unlawful detention. Indeed, the Court has justified the procedural default rule on the ground that an applicant "who has failed to meet the State's procedural requirements ... has deprived the state courts of an opportunity to address those claims in the first instance." ${ }^{94}$

To be sure, the procedural default doctrine does not precisely replicate the unclean hands defense. In particular, the failure to comply with state procedural rules is not completely equivalent to a legal or moral wrong committed against the State. ${ }^{85}$ Although an applicant's noncompliance arguably injures the state by depriving it of an opportunity to correct its error, the State undoubtedly could waive enforcement of its procedural rules to reach the applicant's claim. In that way, the wrong is perhaps better described as forcing the State to choose between its interest in enforcing its generally applicable procedural rules and its interest in having the state court reach the merits of the applicant's claim.

In addition, it is often the applicant's lawyer, not the applicant, who fails to comply with the state's procedural rules. The lawyer may well be acting as the applicant's agent, and the lawyer's conduct therefore is attributable to the applicant, but it is not clear that the unclean hands defense considers the conduct of anyone except the litigant himself. ${ }^{86}$ The procedural default doctrine therefore sweeps more broadly than unclean hands. Despite these differences, the two doctrines share sufficient characteristics to ground the procedural default doctrine in equitable principles.

3. Abuse of the Writ.-The abuse of the writ doctrine also has roots in equitable principles. As the Court has noted, the rationale for this limitation parallels the justifications for res judicata, ${ }^{87}$ a doctrine with a long history that predates even the English common law split between

\footnotetext{
${ }^{83}$ See, e.g., Barefoot v. Estelle, 463 U.S. 880, 887-88 (1983) (characterizing the direct appeal as the "primary avenue for review of a conviction or sentence," and the federal habeas remedy as a "secondary and limited" avenue)

${ }^{84}$ Coleman v. Thompson, 501 U.S. 722, 732 (1991).

85 At most, such default signifies negligence by the applicant or, more usually, his attorney.

${ }^{86}$ See, e.g., Art Metal Works, Inc. v. Abraham \& Straus, Inc., 70 F.2d 641, 646 (2d Cir. 1934) (Hand, J., dissenting) (“The reasons which justify imputing liability to a principal for his agent's acts ... have nothing in common with [unclean hands, which] ... stands upon the court's repugnance to the suitor personally ...."), adopted as opinion of the court on rehearing, 107 F.2d 944 (2d Cir. 1939) (per curiam).

${ }^{87}$ See, e.g., Felker v. Turpin, 518 U.S. 651, 664 (1996) (calling the abuse of the writ doctrine "a modified res judicata rule").
} 
courts of law and equity ${ }^{88}$ English common law courts adopted both res judicata and collateral estoppel. ${ }^{89}$ And although res judicata may not have been recognized as an equitable defense in early English law (unlike adequacy of legal remedies, unclean hands, or laches), ${ }^{90}$ there is a long history in the United States of equity courts using the doctrine to block suits. ${ }^{91}$ This is no surprise. The essential justification for res judicata, after all, emanates from basic considerations of fairness. A litigant, so the argument goes, rightly deserves one bite at the apple, but not two. Otherwise, courts would facilitate opportunities for harassing defendants or subjecting them to unfairly inconsistent results, in contravention of the principles guiding practice in equitable courts. ${ }^{92}$

4. Statute of Limitations.-Finally, the statute of limitations enacted in AEDPA mirrors laches, another traditional equitable defense. Under the laches doctrine, as initially conceived, a suit is barred if one has acted with unreasonable delay in bringing claims, thereby prejudicing the party against whom relief is sought. ${ }^{93}$ Over time, courts of equity refined the laches defense to make it resemble closely the defense found in statutes of limitations. Of particular importance, equity courts looked to the statutes of limitations that would govern similar suits at law and then applied those

88 See Note, Developments in the Law: Res Judicata, 65 HARV. L. REV. 818, 820 (1952) (noting
hat res judicata principles were "early adopted in English law").
89 See id. at 820-21.
90 Equitable estoppel, which prevents a party from asserting contrary positions as to the same issue, was a traditional equitable defense, see T. Leigh Anenson, The Triumph of Equity: Equitable Estoppel in Modern Litigation, 27 REV. LiTIG. 377, 384-86 (2008), but it is not clear that res judicata was similarly established.

91 See, e.g., Jacobson v. First Nat'1 Bank of Bloomingdale, 31 A.2d 406, 408 (N.J. Cir. Ct. 1943) ("[Res judicata] applies alike to decrees of courts of equity and judgments of courts of law, and the final determination in either court may be invoked as a bar or estoppel in the other."); Brown v. Thompson, 128 S.E. 309, 312 (W. Va. 1925) ("Either party . . . is estopped from alleging in a suit at common law or in chancery anything inconsistent with any point, which has been before adjudicated by a court of either common law or chancery ...." (quoting Poole v. Dilworth, 26 W. Va. 583 (1885))); Hayes v. Frohock, 47 So. 343, 343 (Fla. 1908) (holding that a determination made in a court of law is binding in a subsequent equity proceeding).

92 Rein v. David A. Noyes \& Co., 665 N.E.2d 1199, 1208 (Ill. 1996) (reasoning that the policy behind res judicata "is to protect the defendant from harassment and the public from multiple litigation"); Lewis A. Grossman, The Story of Parklane: The "Litigation Crisis" and the Efficiency Imperative, in CiVIL Procedure STORIES 405, 408 (Kevin M. Clermont ed., 2008) (noting that courts and scholars traditionally defend res judicata because it "protects litigants from harassment through the litigation of the same claim or issue" (quoting Allan D. Vestal, Res Judicata/Preclusion by Judgment: The Law Applied in Federal Courts, 66 MICH. L. REV. 1723, 1723 (1968))).

93 See City of Sherrill v. Oneida Indian Nation of N.Y., 544 U.S. 197, 217 (2005) (“[L]aches, a doctrine [that] focuse[s] on one side's inaction and the other's legitimate reliance, may bar ... claims for equitable relief."); Catherine T. Struve, Direct and Collateral Federal Court Review of the Adequacy of State Procedural Rules, 103 ColuM. L. REV. 243, 257 n.43 (2003) ("The doctrine of laches... bar[s] equitable relief in cases where a claimant's delay has resulted in prejudice to the defendant."). 
limitations even without a showing of prejudice. ${ }^{94}$ In addition, state legislatures began to pass statutes of limitations for equity suits, and courts did not hesitate to apply them..$^{95}$ AEDPA's one-year statute of limitations, ${ }^{96}$ although short, ${ }^{97}$ mirrors the equitable considerations that underlie the laches doctrine. Thus, all four of these gatekeeping doctrines have connections with traditional equitable principles.

\section{B. Focus on the Applicant's Conduct}

Each of these four bars turns on the applicant's conduct, a factor that traditionally has been an equitable consideration. ${ }^{98}$ The focus on the applicant's conduct is especially apparent in the abuse of the writ and exhaustion doctrines, but it also animates the procedural default and statute of limitations defenses. Indeed, as discussed below, each of these four bars contains exceptions for applicants who were unable to comply with the requirements for reasons beyond their control. ${ }^{99}$

The abuse of the writ doctrine especially focuses on the applicant's conduct. Upon filing a first federal habeas petition, the applicant has notice that, absent extraordinary circumstances relating to the unavailability of the claim at the time, all claims must be asserted together. ${ }^{100}$ To be sure, the "abuse" this doctrine targets often has less to do with the applicant's conduct than his lawyer's. Much of the criticism of this doctrine therefore stems from concerns about holding clients responsible for their lawyers' errors. Even so, the acts of an agent are normally attributed to the

${ }^{94}$ See, e.g., Russell v. Todd, 309 U.S. 280, 289 (1940) ("[E]quity will withhold its remedy if the legal right is barred by the local statute of limitations."); Michael E. Baughman, Comment, Defining the Boundaries of the Adverse Domination Doctrine: Is There Any Repose for Corporate Directors?, 143 U. PA. L. REV. 1065, 1072 (1995) ("By the end of the nineteenth century, equity courts generally adopted the limitation periods found in analogous statutes of limitations at law.").

95 See, e.g., Poag v. Flories, 317 S.W.3d 820, 825-26 (Tex. App. 2010) (applying statute of limitations for equity suits to quiet title action); Bird v. Chandler, 144 S.E. 265, 265-66 (Ga. 1928) (barring suit for accounting based on the statute of limitations for equity suits).

9628 U.S.C. $\$ 2244$ (d) (2006).

97 Compare id. (setting forth a one-year statute of limitations), with id. § 1658(a) (providing a fouryear statute of limitations as a default rule in civil actions arising under Acts of Congress).

98 See, e.g., Brown v. Lake Superior Iron Co., 134 U.S. 530, 535 (1890) (“[T]he maxim, 'He who seeks equity must do equity,' is as appropriate to the conduct of the defendant as to that of the complainant."); In re Prudhomme, 43 F.3d 1000, 1003 (5th Cir. 1995) (tolling a statute of limitations in bankruptcy due to the inequitable conduct of the parties); Brendan D. Cummins, The Thorny Path to Thornhill: The Origins at Equity of the Free Speech Overbreadth Doctrine, 105 YALE L.J. 1671, 1678 (1996) (noting that courts of equity modify injunctions if they are so expansive as to encompass the "conduct of innocent parties").

99 See infra Part II.C.

100 See McCleskey v. Zant, 499 U.S. 467, 489 (1991) (noting that applicants are on notice at the time of the initial filing and can abuse the writ "regardless of whether the failure to raise [the claim] earlier stemmed from a deliberate choice"). 
principal, ${ }^{101}$ and so this bar reflects consideration of a factor emphasized by courts of equity for generations.

The exhaustion requirement also focuses on the applicant's own conduct - namely, whether he fairly presented the issue to the state court so that it could correct the claimed legal error. And, unlike the other four gatekeepers, the exhaustion bar permits applicants with unexhausted claims to cure that shortcoming even after filing the federal petition. ${ }^{102}$ Particularly for this reason, courts can and do attribute any failure to exhaust other available remedies to the informed choice of the applicant himself.

The procedural default doctrine likewise responds to the applicant's conduct - or at least the conduct of his lawyer. Importantly, this defense is not available unless the state procedural rule was "firmly established and regularly followed." 103 Thus, the applicant (or at least his counsel) must be put on fair notice of the need to comply with such rules at the critical point of decision before the applicant suffers forfeiture of his habeas claim. ${ }^{104}$ This doctrine, like the abuse of the writ defense, has been criticized both on the ground that applicants should not be prejudiced by their attorneys' mistakes ${ }^{105}$ and because in some cases, the rules are hard to discover for even the best lawyers. But these arguments take issue with general principles of agency law rather than with the procedural default doctrine itself.

Finally, the statute of limitations focuses on the applicant's own conduct in the most direct way: it imposes a bar based on the applicant's

101 Note, The Power of an Agent to Bind His Principal by Acts Beyond His Actual or Apparent Authority, 42 HARV. L. REV. 685, 685 (1929) (noting how courts recognize agents' acts as binding the principal even beyond instances of real or apparent authority).

102 See Slack v. McDaniel, 529 U.S. 473, 487 (2000) (noting that dismissal for failure to exhaust leaves applicants with the option of subsequently exhausting state remedies and returning to federal court without running afoul of the abuse of the writ doctrine); Rose v. Lundy, 455 U.S. 509, 520 (1982) (finding that a total exhaustion rule would not prevent applicants from obtaining speedy federal relief because they retain the option of amending their petitions to eliminate unexhausted claims or returning to state court to exhaust state remedies before returning to federal court).

103 Lee v. Kemna, 534 U.S. 362, 376 (2002) (quoting James v. Kentucky, 466 U.S. 341, 348 (1984)); see also Ford v. Georgia, 498 U.S. 411, 424-25 (1991) (holding state rule not "firmly established" when retroactively applied); James v. Kentucky, 466 U.S. 341, 348-49 (1984) (finding state rule distinguishing between jury instructions and admonitions to be arid formalism, not firmly established and generally followed).

104 Of course, it can be very difficult to comply with at least some of those rules, such as the contemporaneous objection rule requiring defendants to object during the course of the trial to preserve an issue on appeal. See Stephen B. Bright, Preserving Error at Capital Trials, CHAMPION, April 1997, available at http://www.nacdl.org/CHAMPION/ARTICLES/97apr03.htm (noting that "[p]reserving all grounds can be very difficult in the heat of battle during trial").

105 See, e.g., Rae K. Inafuku, Comment, Coleman v. Thompson-Sacrificing Fundamental Rights in Deference to the States: The Supreme Court's 1991 Interpretation of the Writ of Habeas Corpus, 34 SAnTA Clara L. Rev. 625, 651 (1994) (asserting that the problem with Coleman was that it forced clients to lose state and federal habeas appeals because of their attorneys' mistakes, even if they could have raised an ineffective assistance challenge on direct review). 
lack of diligence in presenting claims in federal court. To be sure, AEDPA's limitations period is notably short. ${ }^{106}$ But the bar nonetheless relates to a factor within the control of the applicant and his attorney. ${ }^{107}$ Thus, each of these habeas bars closely correlates to the applicant's voluntary conduct.

\section{Equitable Exceptions}

In addition to their focus on the individual applicant's conduct, the existence of individualized exceptions to each of these bars demonstrates their equitable heritage in an especially powerful way. In particular, these exceptions reflect instances in which the applicant's conduct in a given case could be deemed blameless, or the applicant has a distinctively significant need for redress, or both. To be sure, AEDPA's codifications of these gatekeeping bars-particularly abuse of the writ and the statute of limitations - has limited the availability of the equitable exceptions. Even with AEDPA's restrictions of the remedy, however, equitable exceptions to the bars still exist.

1. Procedural Default and Abuse of the Writ Exceptions.-As formulated by the Supreme Court, both the procedural default and abuse of the writ doctrines provide an exception if the applicant can establish a justifiable "cause" for the default and "actual prejudice as a result of the alleged violation of federal law." 108 Given the focus on the applicant's conduct, the equitable origins of this exception can be easily discerned. Indeed, the Court has explained that allowing claims that meet the cause and prejudice exception to go forward "reflect[s] an equitable judgment that only where a prisoner is impeded or obstructed in complying with the State's established procedures will a federal habeas court excuse the

\footnotetext{
10628 U.S.C. $§ 2244$ (d) (2006) (announcing a one-year filing period).

107 Most complaints about this bar stem from attorney error in calculating the time periods. See, e.g., Marni von Wilpert, Comment, Holland v. Florida: A Prisoner's Last Chance, Attorney Error, and the Antiterrorism and Effective Death Penalty Act's One-Year Statute of Limitations Period for Federal Habeas Corpus Review, 79 FordHAM L. REV. 1429, 1433 (2010) (noting the "alarming trend" of attorneys failing to file their clients' petitions on time). But see Lawrence v. Florida, 549 U.S. 327, 336 37 (2007) ("Attorney miscalculation is simply not sufficient to warrant equitable tolling, particularly in the postconviction context where prisoners have no constitutional right to counsel."). Holding the applicant responsible for the attorney's errors, of course, raises significant issues that perhaps are better addressed on different grounds. See, e.g., Maples v. Thomas, 132 S. Ct. 912, 924 (2012) (holding that "a client cannot be charged with the acts or omissions of an attorney who has abandoned him").

${ }^{108}$ Coleman v. Thompson, 501 U.S. 722, 750 (1991); see also McCleskey v. Zant, 499 U.S. 467, 494 (1991) (holding that the cause and prejudice standard developed in the procedural default context also applies to the abuse of the writ doctrine). As discussed below, in 1996, Congress amended the statute to narrow the cause and prejudice exception that applies to the abuse of the writ doctrine. See infra notes 123-25 and accompanying text. There is one additional narrow exception if the applicant can establish that a failure to consider the claim would result in a fundamental miscarriage of justice. See infra notes 117-18.
} 
prisoner from the usual sanction of default." ${ }^{109}$ In other words, where the failure to properly raise a claim (either in accordance with state rules or in an initial federal petition) cannot fairly be attributed to the applicant's conduct, these bars-grounded in equity-should not preclude consideration of a potent or meritorious constitutional claim.

The Court in Martinez v. Ryan discussed at length the equitable nature of the cause and prejudice exception in the context of the procedural default bar. ${ }^{110}$ State law expressly required the applicant to raise any claim of ineffective assistance of counsel in a collateral proceeding, rather than on direct review. ${ }^{111}$ Martinez's appellate counsel filed his appeal, and while the appeal was pending, she also filed a state habeas petition on Martinez's behalf. The attorney's brief in support of collateral relief did not raise any claim based on ineffective assistance of trial counsel, and the state habeas court dismissed the petition. ${ }^{12}$ When Martinez thereafter tried to argue ineffective assistance of his trial counsel in a second state habeas petition, the state court refused to reach the merits of the claim because he had not raised it in his first petition. On federal habeas review, the State argued procedural default, since the state court invoked its successive petition rule to bar consideration of his claim. Martinez then argued that his state habeas counsel's ineffectiveness constituted cause for that procedural default. ${ }^{113}$

The Court declined to decide whether applicants have a constitutional right to effective assistance of counsel in initial-review collateral proceedings (i.e., proceedings in which an applicant raises claims that could not be brought on direct review). Instead, it propounded an "equitable ruling" that an applicant can establish "cause" to excuse procedural default when he can show either ineffective assistance by an attorney appointed in initial-review collateral proceedings or that no counsel was appointed in such proceedings. ${ }^{114}$ The Court went to great lengths to emphasize that this rule stemmed from its equitable power to hear substantial claims that were procedurally defaulted through no fault of the applicant. ${ }^{15}$ And more recently, the Court has broadened Martinez's equitable exception to encompass not only instances in which state law expressly requires the defendant to raise ineffective assistance of counsel claims on direct review, but also situations in which a defendant may

109 Martinez v. Ryan, 132 S. Ct. 1309, 1318 (2012).

110 Id. at $1318-19$.

111 Id. at 1313. The Court called these "initial-review collateral proceedings." Id. at 1315.

112 Id. at 1314. In fact, counsel contended that Martinez did not have any meritorious issues. Id.

113 Id. at $1314-15$.

114 Id. at $1318-19$

115 See id. at 1318 ("Allowing a federal habeas court to hear a claim of ineffective assistance of trial counsel when an attorney's errors (or the absence of an attorney) caused a procedural default in an initial-review collateral proceeding acknowledges, as an equitable matter, that the initial-review collateral proceeding, if undertaken without counsel or with ineffective counsel, may not have been sufficient to ensure that proper consideration was given to a substantial claim."). 
present the claim on direct review, but the state's procedures make it "virtually impossible" for appellate counsel to do so. ${ }^{116}$

Both the abuse of the writ and procedural default doctrines also are subject to an additional narrow exception permitting habeas relief where an applicant cannot establish cause and prejudice but can demonstrate either a "fundamental miscarriage of justice" or "actual innocence." 117 This standard imposes an extremely high burden on the applicant, and very few - or no - applicants have been successful in invoking it. ${ }^{118}$ But even if it provides only the slimmest possibility for relief, the Court still has fashioned a mechanism for courts to grant relief to otherwise barred claims based on an individualized consideration of the applicant's claim. ${ }^{119}$ For procedural default, then, the cause and prejudice exception (along with the individualized consideration of the actual innocence exception, even if the possibility of relief is very slim) provides a meaningful opportunity for applicants to avoid the bar on relief.

In contrast to the cause and prejudice exception to the procedural default bar, the abuse of the writ doctrine's cause and prejudice exception presents a more problematic story. This is so both because the Court accompanied its recognition of the exception with an expansion of the abuse of the writ bar and because Congress has significantly raised the standard for showing cause and prejudice to excuse abuse of the writ. In McCleskey v. Zant, the Court held that a showing of cause and prejudice could excuse an abuse of the writ. ${ }^{120}$ Before reaching that conclusion, however, the Court first expanded the scope of the abuse of the writ bar by holding it applicable not just to those who "deliberate[ly] abandon[ed]" their claims in the first petition, but also to any applicant who failed to raise a claim in the first petition even if that failure resulted from neglect rather than deliberate choice. ${ }^{121}$ As a result, although the Court recognized the

\footnotetext{
116 See Trevino v. Thaler, 133 S. Ct. 1911, 1918 (2013) (quoting Robinson v. State, 16 S.W.3d 808, 810-11 (Tex. Crim. App. 2000)).

117 See, e.g., Sawyer v. Whitley, 505 U.S. 333, 339-40 (1992) ("We have previously held that even if a state prisoner cannot meet the cause and prejudice standard, a federal court may hear the merits of the successive claims if the failure to hear the claims would constitute a 'miscarriage of justice' ... or 'actual innocence' .....').

118 See Schlup v. Delo, 513 U.S. 298, 321 (1995) (“[H]abeas corpus petitions that advance a substantial claim of actual innocence are extremely rare."); Doe v. Menefee, 391 F.3d 147, 161 (2d Cir. 2004) (noting that "credible claims of actual innocence are "extremely rare"" (quoting Schlup, 513 U.S. at 321-22)); see also Stephen Reinhardt, The Anatomy of an Execution: Fairness v. "Process," 74 N.Y.U. L. REV. 313, 317 n.21 (1999) (observing that the author could find no cases that had successfully argued this exception). The author has been unable to identify any cases in which an applicant successfully invoked the actual innocence exception in the fourteen years since Judge Reinhardt conducted that same search.

119 See In re Davis, 130 S. Ct. 1, 1-2 (2009) (Stevens, J., concurring) (noting that a claim of actual innocence, particularly in a capital case, may alter the application of certain AEDPA requirements).

120499 U.S. 467, 494 (1991).

121 See id. at 489.
} 
cause and prejudice exception to excuse certain instances of excusable neglect by the applicant, that recognition was overshadowed by its conclusion that the abuse of the writ doctrine applied to negligent (in addition to deliberate) failures to raise claims in initial petitions. ${ }^{122}$

Of more importance, when Congress codified the abuse of the writ bar in AEDPA, it replaced the common law cause and prejudice standard with a much more limited exception. ${ }^{123}$ Under AEDPA, an abuse of the writ can be excused if:

(B)(i) the factual predicate for the claim could not have been discovered previously through the exercise of due diligence; and (ii) the facts underlying the claim, if proven and viewed in light of the evidence as a whole, would be sufficient to establish by clear and convincing evidence that, but for constitutional error, no reasonable factfinder would have found the applicant guilty of the underlying offense. ${ }^{124}$

The statute's requirement that the applicant establish by clear and convincing evidence that no reasonable factfinder would have found him guilty absent the constitutional error significantly raises the cause and prejudice standard for abuse of the writ, which previously had required only a showing that there was a "substantial likelihood" that the error prejudiced his chances of a different verdict. ${ }^{125}$ That fact notwithstanding, the exception still provides individualized consideration of both the applicant's fault in failing to raise the claim in the first petition and the merits of his claim. ${ }^{126}$

122 See Reinhardt, supra note 118, at 317 \& n.20 (noting the Rehnquist Court's expansion of the abuse of the writ doctrine and general "assault" on the habeas writ through cases like McCleskey). To phrase it slightly differently, had the Court in McCleskey held that the abuse of the writ doctrine applied only to instances in which the petitioner made a deliberate choice not to raise the claim in his original federal habeas petition, the cause and prejudice exception would not have been needed.

12328 U.S.C. $\S 2244(\mathrm{~b})(2)(\mathrm{A})-(\mathrm{B})$ (2006), amended by AEDPA, Pub. L. No. 104-32, § 106, 110 Stat. 1214, 1221 (1996); see also In re Jones, 226 F.3d 328, 332 n.1 (4th Cir. 2000) ("[R]ather than showing that a second or successive motion is not an abuse of the writ, a movant must satisfy the more stringent [AEDPA] gatekeeping standards."); In re Minarik, 166 F.3d 591, 595 (3d Cir. 1999) (noting that the "more rigorous" AEDPA standard replaced the common law cause and prejudice test).

12428 U.S.C. $\S 2244$ (b)(2)(B)(i)-(ii), amended by AEDPA $\S 106$. The Act also has an exception if the claim relies on a "new rule of constitutional law, made retroactive to cases on collateral review by the Supreme Court, that was previously unavailable." Id. § 2244(b)(2)(A).

${ }^{125}$ See United States v. Frady, 456 U.S. 152, 174 (1982); Williams v. United States, 98 F.3d 1052, 1054 (8th Cir. 1996).

126 The statute also provides an exception for claims that "rely[] on a new rule of constitutional law, made retroactive to cases on collateral review by the Supreme Court, that was previously unavailable." 28 U.S.C. $§ 2244($ b)(2)(A), amended by AEDPA $§ 106$. This second exception, like the first, stems from the fact that the applicant cannot be faulted for failing to raise a claim based on a new rule of constitutional law in the earlier petition. As discussed infra Part III.A, the Court in Teague v. Lane, 489 U.S. 288 (1989), narrowed the instances in which new rules will apply retroactively. Subject to narrow exceptions, the Court held that new procedural constitutional rules will not apply retroactively to habeas cases that were final at the time the Court decided the new rule, but new substantive constitutional rules will. 
2. Exceptions to the Exhaustion Requirement.-The exhaustion requirement is also subject to exceptions derived from equity. In particular, the Supreme Court has held that so long as a state court has resolved an issue on direct review, the applicant has exhausted the claim and does not have to pursue state collateral review of that issue prior to filing a federal habeas petition on that matter. ${ }^{127}$ This rule parallels the maxim that equity does not require an idle or meaningless gesture. ${ }^{128}$ In other words, once the state appellate courts have had the opportunity to consider the issue, it makes little sense to "mandate recourse to state collateral review whose results have effectively been predetermined." 129

In addition, because the exhaustion requirement focuses on the applicant's conduct, it requires only that he has fairly and properly presented the issue to a state court. ${ }^{130}$ Even if a state court fails to rule on a properly presented claim, the applicant will have adequately exhausted his remedies as long as he has attempted to obtain a state resolution of the issue. ${ }^{131}$ The exhaustion requirement, moreover, does not apply unless a state remedy actually exists at the time the applicant files his habeas petition; otherwise, there is no process to exhaust. ${ }^{132}$ Finally, because federal courts permit applicants to cure any failures to exhaust, diligent applicants can cure any exhaustion bar.

3. Exceptions to the Statute of Limitations.-Equitable considerations also drive the three exceptions to AEDPA's statute of limitations, each of which comes into play when the applicant's failure to timely file was beyond his control. First, if delay resulted from an "impediment to filing an application created by State action in violation of the Constitution or laws of the United States," the statute of limitations period begins only when the state removes the impediment. ${ }^{133}$ Second, as

\footnotetext{
127 See, e.g., Castille v. Peoples, 489 U.S. 346, 350 (1989) ("[O]nce the state courts have ruled upon a claim, it is not necessary for a petitioner 'to ask the state for collateral relief, based upon the same evidence and issues already decided by direct review." (quoting Brown v. Allen, 344 U.S. 443, 447 (1953))). This exception existed both before and after Congress's codification of the exhaustion requirement.

128 See, e.g., Roger S. Braugh, Jr. \& Paul C. Sewell, Equitable Bill of Review: Unraveling the Cause of Action that Confounds Texas Courts, 48 BAYLOR L. REV. 623, 631 (1996) ("[E]quity will not do a vain thing.").

129 Castille, 489 U.S. at 350

130 See Smith v. Digmon, 434 U.S. 332, 333 (1978) (per curiam) (noting that whether the exhaustion requirement is met depends on the applicant's conduct, not what the state court chooses to do with the claims presented).

131 See id. at 333-34. Of course, as discussed supra Part I, the applicant must have complied with the state's procedural rules in presenting the claim.

132 See, e.g., Engle v. Isaac, 456 U.S. 107, 125 n.28 (1982); Yackle, supra note 77.

13328 U.S.C. § 2244(d)(1)(B) (2006); see, e.g., Critchley v. Thaler, 586 F.3d 318, 318 (5th Cir. 2009) (holding that the state court's failure to file a prisoner's state habeas petition constituted a statecreated impediment under AEDPA).
} 
with the abuse of the writ doctrine, if the Supreme Court announces a new constitutional rule made retroactively applicable to habeas cases, the limitations period starts when the Supreme Court announces that ruling. ${ }^{134}$ Finally, if the factual predicate for the claim could not have been "discovered through the exercise of due diligence," the statute of limitations begins when the factual predicate could have been discovered. ${ }^{135}$ In keeping with the focus on the party's conduct that guided equitable courts, each of these exceptions hinges on a circumstance that makes compliance with the statute effectively impossible, so that noncompliance is not fairly attributable to the applicant's choice.

In addition, the Court has held that the limitations period may be equitably tolled where the applicant has been "pursuing his rights diligently" and "some extraordinary circumstance stood in his way and prevented timely filing." ${ }^{136}$ This may present a high bar ${ }^{137}$ but its equitable nature could not be more apparent. Tolling turns on both the applicant's conduct and the reasons for the delay, factors central to equitable consideration.

Finally, the Court recently held that the "actual-innocence" or "fundamental miscarriage of justice" gateway applies to the statute of limitations bar as well as to the abuse of the writ and procedural default bars. ${ }^{138}$ The Court emphasized that "tenable actual-innocence gateway pleas are rare, ${ }^{139}$ and as discussed above, it appears that few, if any, courts have found that a petitioner has made a sufficiently compelling claim of actual innocence to warrant relief, ${ }^{140}$ but the gateway at least provides an avenue of relief for the most compelling claims.

All of these exceptions have been criticized on the ground that they are too narrow. ${ }^{141}$ And an equitable balancing may well counsel in favor of broader exceptions. But at the very least, these individualized exceptions,

13428 U.S.C. $\S 2244(d)(1)(C)$.

135 Id. $\S 2244(\mathrm{~d})(1)(\mathrm{D})$.

${ }^{136}$ Holland v. Florida, 130 S. Ct. 2549, 2560-62 (2010) (internal quotation marks omitted) (holding that equitable tolling applies to one-year filing period in part because of "the fact that equitable principles have traditionally governed the substantive law of habeas corpus").

137 See, e.g., Dillon v. Conway, 642 F.3d 358, 363 (2d Cir. 2011) ("As a general matter, we set a high bar to deem circumstances sufficiently 'extraordinary' to warrant equitable tolling.").

138 See McQuiggin v. Perkins, 133 S. Ct. 1924, 1928 (2013).

${ }^{139}$ Id. Notably, the Court concluded that Perkins's showing of actual innocence was not sufficiently compelling to entitle him to use the gateway around the statute of limitations bar. Id. at 1936.

140 See supra Part II.C.1.

141 See, e.g., John H. Blume, AEDPA: The "Hype" and the "Bite," 91 CORNELl L. REV. 259, 289 (2006) (criticizing AEDPA's statute of limitations for depriving without sufficient reason "thousands of potential habeas petitioners of any federal review of their convictions, and in some cases, their death sentences"); John H. Blume et al., In Defense of Noncapital Habeas: A Response to Hoffman and King, 96 CORNELL L. REV. 435, 475 (2011) (highlighting how the complexity and unyielding nature of 28 U.S.C. § 2254(d) encourages not only early filings, but also dismissal of otherwise meritorious claims). 
like the bars themselves, demonstrate the equitable considerations underlying the habeas remedy.

\section{TEAGUE'S EQUITABLE OUTLIER STATUS}

Unlike the four gatekeeping requirements discussed above, the nonretroactivity rule from Teague does not reflect principles of equity. It has no analogue in traditional equitable doctrine, it applies without regard to either the applicant's conduct or the strength of his claim, and it has no exceptions that take account of the individual applicant's lack of fault. Understanding the origins and basic operation of the Teague rule helps to demonstrate its status as an inequitable outlier in the law of habeas corpus.

\section{A. Teague's History and Operation}

Teague announced a sweeping new rule. Until 1965, federal courts routinely applied the Supreme Court's new rules of criminal procedure to all cases that came before them, whether on direct review or in habeas proceedings. ${ }^{142}$ Indeed, the Court sometimes declared new constitutional rules in habeas cases. ${ }^{143}$ In Linkletter $v$. Walker, however, the Court concluded that the Constitution did not require it to apply its decisions retroactively and set forth a new rule for assessing retroactivity. ${ }^{144}$ Under the Linkletter rule, the Court was to "weigh the merits and demerits in each case by looking to the prior history of the rule in question, its purpose and effect, and whether retrospective operation will further or retard its operation." 145

Applying those principles to its holding in Mapp v. Ohio, ${ }^{146}$ the Linkletter Court concluded that Mapp's new spin on the Fourth Amendment exclusionary rule ${ }^{147}$ should not apply retroactively to cases "finally decided"-i.e., cases that had run the course of direct appeal and petition for certiorari-prior to Mapp. ${ }^{148}$ Linkletter led to complaints that it was inconsistently applied. ${ }^{149}$ In several opinions, Justice Harlan urged the

\footnotetext{
142 See Linkletter v. Walker, 381 U.S. 618, 628 (1965) (noting that the Court previously had "applied new constitutional rules to cases finalized before the promulgation of the rule").

${ }^{143}$ See, e.g., Stack v. Boyle, 342 U.S. 1, 5 (1951) (holding in a habeas proceeding that bail "must be based upon standards relevant to the purpose of assuring the presence of that defendant" (emphasis added)).

144381 U.S. at 629.

145 Id.

146367 U.S. 643 (1961).

147 Id. at 654-55 (holding that the exclusionary rule applies to state prosecutions).

148 Linkletter, 381 U.S. at 622 n.5.

149 See, e.g., AleXANDer M. Bickel, The Supreme Court AND the IDEA OF Progress 54-57 (1978); Francis X. Beytagh, Ten Years of Non-Retroactivity: A Critique and a Proposal, 61 VA. L. ReV. 1557 (1975); Jonathan Mallamud, Prospective Limitation and the Rights of the Accused, 56 IowA L. Rev. 321 (1970); Ralph A. Rossum, New Rights and Old Wrongs: The Supreme Court and the Problem of Retroactivity, 23 EMORY L.J. 381 (1974).
} 
Court to adopt a standard that would make new constitutional rules applicable to all cases that were not final on direct review at the time of the Court's new rule, but inapplicable to cases that were final on direct review at that time. ${ }^{150} \mathrm{He}$ argued that this standard would bring greater clarity and consistency to the Court's treatment of retroactivity issues.

Twenty years after Linkletter, Justice Harlan's argument bore fruit when the Court announced the Teague gatekeeping limitation, under which most new rules would not apply retroactively to finally decided cases. ${ }^{151}$ The Court in Teague discussed at length Justice Harlan's earlier observations in concluding that collateral habeas review and direct appellate review serve different purposes. ${ }^{152}$ While direct review seeks to protect the defendant's individual rights, "the threat of habeas serves as a necessary additional incentive for trial and appellate courts throughout the land to conduct their proceedings in a manner consistent with established constitutional standards." 153 Thus, the Court concluded, because the "interests of comity and finality must ... be considered in determining the proper scope of habeas review" and because applying new rules to final convictions imposes costs on states that "generally far outweigh the benefits of this application," Justice Harlan's direct-review-centered approach to retroactivity struck the proper legal balance. ${ }^{154}$

Under the Teague gatekeeping limitation, if a Supreme Court decision announces a "new rule" of criminal procedure, that rule may not be invoked in pending federal habeas proceedings reviewing state imprisonment ${ }^{155}$ unless it falls within one of two "exceptions," the first of which is more properly characterized as a definition of the scope of the Teague rule rather than an "exception" and the second of which appears to exist only in theory. ${ }^{156}$ First, the Court limited the retroactivity ban to new "procedural" rules that "regulate only the manner of determining the

\footnotetext{
150 See Mackey v. United States, 401 U.S. 667, 675, 677-81 (1971) (Harlan, J., concurring in the judgment in part and dissenting in part); Desist v. United States, 394 U.S. 244, 256, 258 (1969) (Harlan, J., dissenting).

151 Teague v. Lane, 489 U.S. 288, 309-10 (1989) (O’Connor, J., plurality opinion). The "new rule" portion of Justice O'Connor's Teague opinion drew only a plurality of the Court, but a majority of the Court reaffirmed Teague later that term in Penry v. Lynaugh, 492 U.S. 302, 303 (1989).

152 Teague, 489 U.S. at 305-07 (O’Connor, J., plurality opinion).

153 Id. at 306 (quoting Desist, 394 U.S. at 262-63 (1969) (Harlan, J., dissenting)).

154 Id. at 308, 310 (quoting Solem v. Stumes, 465 U.S. 638, 654 (1984) (Powell, J., concurring in the judgment)).

${ }^{155}$ The Court in Teague did not address whether its nonretroactivity rule applied to federal prisoners seeking habeas relief pursuant to 28 U.S.C. $\S 2255$. Teague, 489 U.S. at 327 n. 1 (Brennan, J., dissenting). The Court since has declined to address the issue, see, e.g., Danforth v. Minnesota, 552 U.S. 264, 269 n.4 (2007), including most recently in Chaidez v. United States, 133 S. Ct. 1103, 1113 n.16 (2013), in which the Court held that the issue of Teague's applicability to federal prisoners had not been properly preserved for decision.

156 See infra notes 161-64 and accompanying text.
} 
defendant's culpability." "157 If a new rule is substantive, i.e., it makes certain conduct noncriminal or prohibits certain penalties for a particular class of offenders, then Teague does not apply, and the new rule applies equally to cases on direct and collateral habeas review. ${ }^{158}$ In recent years, the Court has decided several substantive (rather than procedural) Eighth Amendment cases, concluding that certain categories of offenders cannot be subject to the death penalty or life-without-parole sentences. ${ }^{159}$ Most of the Court's new rulings in criminal cases are procedural, though, and habeas applicants therefore cannot invoke them retroactively. ${ }^{160}$

The Teague rule has one other exception: a new procedural rule may apply retroactively if it constitutes a "watershed rule[] ... implicating the fundamental fairness and accuracy of the criminal proceeding," 161 or, to put it another way, a "bedrock procedural rule[] without which the likelihood of an accurate conviction is seriously diminished." 162 The most important feature of this "exception" is that it apparently exists only in theory. The Court has expressed great skepticism about whether any new constitutional rule could meet this exacting standard. ${ }^{163}$ Indeed, it never has found any new procedural rule that falls within the reach of this so-called exception. ${ }^{164}$

157 Schriro v. Summerlin, 542 U.S. 348, 351-53 (2004) (emphasis omitted). As the Court has noted, although it has sometimes "referred to [substantive] rules . . . as falling under an exception to Teague's bar on retroactive application of procedural rules, they are more accurately characterized as substantive rules not subject to the bar." Id. at 352 n.4 (citation omitted).

158 See Teague, 489 U.S. at 311 (O’Connor, J., plurality opinion); see also Bousley v. United States, 523 U.S. 614, 620-21 (1998) (holding that Bailey v. United States, 516 U.S. 137 (1995), applies retroactively to cases on collateral review because it announced a substantive rule); Penry v. Lynaugh, 492 U.S. 302, 329-30 (1989) (holding that Teague's retroactivity limitations would not apply if, for instance, the Court prohibited the death penalty for certain types of offenders, such as developmentally disabled defendants). The Court's recent cases finding unconstitutional the execution of those who were juveniles when they committed the offense, Roper v. Simmons, 543 U.S. 551 (2005), and of the mentally retarded, Atkins v. Virginia, 536 U.S. 304 (2002), as well as its decision finding unconstitutional juvenile life-without-parole sentences for non-murder offenses, Graham v. Florida, 560 U.S. 48 (2010), all fall in the substantive rules category. In re Sparks, 657 F.3d 258, 262 (5th Cir. 2011) (holding Graham applies retroactively); Bell v. Cockrell, 310 F.3d 330, 332 (5th Cir. 2002) (same, for Atkins); Arroyo v. Dretke, 362 F. Supp. 2d 859, 883 (W.D. Tex. 2005) (same, for Roper).

159 See supra note 158

160 See Whorton v. Bockting, 549 U.S. 406, 406-07 (2007) (holding that the Confrontation Clause rule announced in Crawford v. Washington, 541 U.S. 36 (2004), was procedural); Schriro, 542 U.S. at 353 (holding that the Court's decision in Ring v. Arizona, 536 U.S. 584, 609 (2002), requiring that juries, rather than judges, make threshold findings for death penalty eligibility, announced a procedural rule).

161 Saffle v. Parks, 494 U.S. 484, 495 (1990) (internal quotation marks omitted).

162 Id. at 505 (1990) (Brennan, J., dissenting) (quoting Teague, 489 U.S. at 313) (internal quotation marks omitted)

163 See Teague, 489 U.S. at 313 (O’Connor, J., plurality opinion) (“[W]e believe it unlikely that many such components of basic due process have yet to emerge.").

164 See, e.g., Whorton, 549 U.S. at 406 (holding that Crawford announced a new procedural rule but not a watershed one); Schriro, 542 U.S. at 348 (holding that Ring announced a procedural rule but not a watershed one). Indeed, the Court has suggested that the right to counsel guaranteed by Gideon $v$. 


\section{B. The Effects of Teague}

Teague has sparked much criticism both because of the breadth of the Supreme Court's rule and because of its perceived unfairness. ${ }^{165}$ As to the former critique, the Court, in applying Teague, has defined "new" rules broadly to encompass any rule that either was "susceptible to debate among reasonable minds" at the time the applicant's conviction became final ${ }^{166}$ or was not "apparent to all reasonable jurists." ${ }^{167}$ Stated somewhat differently, federal habeas courts must "determine whether a state court considering [the defendant's] claim at the time his conviction became final would have felt compelled by existing precedent to conclude that the rule [he] seeks was required by the Constitution." 168 If not, then the rule is new. The breadth of this definition cannot be overstated. After all, unanimity among reasonable jurists on any constitutional issue before the Supreme Court is rare. ${ }^{169}$

Even if an applicant relies on cases already decided at the time his conviction became final, moreover, the habeas court still must ascertain whether the applicant's claim seeks to have the prior decision "applied in a novel setting, thereby extending the precedent." 170 If so, Teague bars relief. For instance, a habeas applicant relying on the Court's well-established precedent setting forth the standard for ineffective assistance of counsel claims ${ }^{171}$ cannot seek to apply that standard to any situation the Court has not yet decided. ${ }^{172}$ Indeed, it appears that Teague bars consideration even of

Wainwright, 372 U.S. 335 (1963), may be the one rule that would fall within this exception. Teague, 489 U.S. at 311-12 (O'Connor, J., plurality opinion) (citing Mackey v. United States, 401 U.S. 667, 694 (1971) (Harlan, J., concurring in part and dissenting in part)).

165 See, e.g., Mitchell N. Berman, Constitutional Decision Rules, 90 VA. L. REV. 1, 100 \& n.310 (2004); Barry Friedman, Habeas and Hubris, 45 VAND. L. REV. 797, 823-27 (1992); Meyer, supra note 59, at 438-47; Larry W. Yackle, The Habeas Hagioscope, 66 S. CAL. L. REV. 2331, 2385-99 (1993).

166 Butler v. McKellar, 494 U.S. 407, 414-15 (1990); Christopher S. Strauss, Comment, Collateral Damage: How the Supreme Court's Retroactivity Doctrine Affects Federal Drug Prisoners' Apprendi Claims on Collateral Review, 81 N.C. L. REV. 1220, 1222 (2003).

167 Lambrix v. Singletary, 520 U.S. 518, 527-28 (1997) (emphasis added).

${ }^{168} \mathrm{Id}$. at 527 (alterations in original) (emphasis added) (internal quotation marks omitted).

169 In the Court's 2011-2012 term, approximately 27\% of the Court's merits opinions (including summary reversals) were unanimous in their entirety, and $44 \%$ of the Court's merits opinions were unanimous (meaning that there was at least one concurrence). See Memorandum from SCOTUSblog.com 2 (June 30, 2012), available at http://sblog.s3.amazonaws.com/wp-content/uploads/ 2012/06/SCOTUSblog_Summary_Memo_OT11.pdf. Assuming the reasonableness of all Supreme Court Justices, that means that $56 \%-73 \%$ of Supreme Court opinions are "new rules." Assuming that the views of Supreme Court Justices do not represent the outer bounds of the views of "reasonable jurists," moreover, the percentage of cases deciding "new rules" rises significantly. See Chaidez v. United States, 133 S. Ct. 1103, 1108-11 (2013) (noting that prior to the Court's decision in Padilla v. Kentucky, 559 U.S. 356 (2010), a number of lower federal courts and state courts had reached a different conclusion from Padilla, and therefore concluding that Padilla announced a new rule).

${ }^{170}$ Stringer v. Black, 503 U.S. 222, 228 (1992).

171 See Strickland v. Washington, 466 U.S. 668 (1984)

172 See Chaidez, 133 S. Ct. at 1110-11. 
new claims that can only be considered on habeas, such as a claim that a habeas applicant has a right to effective assistance of counsel on postconviction review. ${ }^{173}$ Thus, Teague bars relief on any claim that relies on any extension of even well-established rules.

The second chief complaint about the Teague rule is that it unfairly compels different results for similarly situated applicants based only on the happenstance of when their cases become final, while turning a blind eye to the consequences of leaving the constitutional error unremedied in one case and not another. ${ }^{174}$ Notably, empirical evidence demonstrates that Teague bars claims in capital cases at a significantly higher rate than in noncapital cases. ${ }^{175}$

An example illustrates the point. In 1983, George Banks was convicted on twelve counts of first-degree murder and sentenced to death in Pennsylvania after he killed thirteen people. ${ }^{176}$ Most of his victims were members of his immediate or extended family, and five of them were his children. ${ }^{177}$ Both at trial and during the sentencing phase, experts disputed the extent and impact of Banks's mental illness. ${ }^{178}$ Defense experts concluded that Banks had long suffered from a severe mental defect (paranoid psychosis with paranoid delusions) and that because of this illness, he was incapable of understanding the nature and quality of his criminal acts, or distinguishing right from wrong. ${ }^{179}$ According to these witnesses, Banks, a former prison guard, was taunted as a child because he had one black and one white parent. He "developed a persecution complex and became obsessed with the paranoid delusion that there were soon to be international race wars and uprisings." ${ }^{180} \mathrm{He}$ armed himself for the coming race wars and spoke of killing himself and his "children rather than see them brought up as he had been in a racist society." 181 The State's experts

\footnotetext{
173 See infra Part IV.A.3.

174 See, e.g., Penry v. Lynaugh, 492 U.S. 302, 341 (1989) (Brennan, J., concurring in part and dissenting in part) ("[A] person may be killed although he or she has a constitutional claim that would have barred his or her execution had this Court only announced the constitutional rule before his or her conviction and sentence became final. It is intolerable that the difference between life and death should turn on such a fortuity of timing ...."); Habeas Corpus Legislation: Hearings on H.R. 4737, H.R 1090, H.R. 1953, and H.R. 3584 Before the Subcomm. on Courts, Intellectual Prop. \& the Admin. of Justice of the H. Comm. on the Judiciary, 101st Cong. 160 (1990) (statement of C.J. Gilbert S. Merritt) ("[Teague $]$ has the effect essentially of freezing the Bill of Rights in habeas cases in its present form, and not allowing ... the [f]ederal courts to review any suggested modification ....").

175 See KING ET AL., supra note 17, at 45, 49 (setting forth data demonstrating that $24 \%$ of capital cases had at least one Teague-barred claim, while less than $1 \%$ of the noncapital claims had a Teaguebarred claim).

${ }^{176}$ Commonwealth v. Banks, 521 A.2d 1, 3, 5-6 (Pa. 1987)

177 Id. at 5-6.

${ }^{178} I d$. at 6-7. In addition, the court held two competency hearings prior to the trial. Id. at 10.

${ }^{179}$ See id.

${ }^{180}$ Id. at 7.

${ }^{181} I d$.
} 
did not dispute the defense experts' diagnosis, but they disagreed with the claim that the delusions made Banks unable to distinguish right from wrong.

Less than one year after Banks's conviction became final, in Mills $v$. Maryland, the Supreme Court held unconstitutional a capital sentencing scheme that required jurors to disregard any mitigating factors upon which they did not unanimously agree. ${ }^{182}$ Two years later, in Boyde v. California, the Court clarified that the Mills rule encompassed sentencing schemes in which there was a reasonable likelihood that the jury interpreted instructions in an unconstitutional manner, i.e., as requiring juror unanimity on mitigating factors. ${ }^{183}$ Banks, both in state post-conviction collateral proceedings $^{184}$ and later in federal habeas proceedings, argued that a reasonable jury could have interpreted the instructions given in his case to unconstitutionally require juror unanimity as to mitigating circumstances, including the existence of his mental disorders. ${ }^{185}$ Given the mitigating evidence Banks presented and the extent to which that evidence was disputed by the parties' expert witnesses, any such juror misunderstanding could have affected the sentence, and in fact the United States Court of Appeals for the Third Circuit concluded that Banks's sentencing was unconstitutional under Mills. ${ }^{186}$ It thus granted habeas relief. ${ }^{187}$

The Supreme Court reversed, holding that Mills articulated a new procedural rule that under Teague did not apply to cases - like Banks'sthat were final when the Court issued Mills. ${ }^{188}$ The Court recognized that the Mills rule was intended to enhance the accuracy of sentencing proceedings and to guard against the risk that "[e]leven of twelve jurors, could, for example, agree that six mitigating circumstances existed, but one holdout juror could nevertheless force the death sentence." ${ }^{189}$ Nonetheless, the Court concluded that because Mills "applies fairly narrowly and works no fundamental shift in our understanding of the bedrock procedural elements essential to fundamental fairness," it did not fall within Teague's watershed-rule exception. ${ }^{190}$ As a result, based only on the date his conviction became final, Banks could not obtain redress for any Mills error, regardless of how grave it was. ${ }^{191}$ Indeed, if his conviction had become

\footnotetext{
182486 U.S. $367,371,384$ (1988).

183494 U.S. 370, 380-81 (1990).

184 Commonwealth v. Banks, 656 A.2d 467, 470-72 (Pa. 1995) (addressing Banks's Mills claim on the merits on post-conviction review).

185 See, e.g., Banks v. Horn, 271 F.3d 527, 535 (3d Cir. 2001).

${ }^{186}$ Id. 544-51.

$187 \mathrm{Id}$. at 551.

188 See Beard v. Banks, 542 U.S. 406, 416, 420 (2004).

189 Id. at 419.

190 Id. at 417, 420 (emphasis omitted) (internal quotation marks omitted).

191 Banks's mother subsequently filed a petition in state court asserting that he was incompetent to be executed under Ford v. Wainwright, 477 U.S. 399 (1986), and seeking a stay of execution.
} 
final only nine months later (or if Mills had been issued nine months earlier), he could have obtained habeas relief. ${ }^{192}$

Banks, of course, could be an extraordinary case. Since 1989, however, the Court has announced new procedural rules in a variety of areas, ${ }^{193}$ many of which would have had significant impact in habeas proceedings in capital cases. For instance, in Ring v. Arizona, the Court held unconstitutional Arizona's capital statute because it permitted judges, rather than juries, to make findings of fact necessary to make the defendant death eligible, in violation of the Fifth and Sixth Amendments. ${ }^{194}$ Two years later, the Court held that Ring announced a new procedural rule that did not apply to convictions already final when it issued Ring. ${ }^{195}$

Similarly, in Simmons v. South Carolina, the plurality opined that if the State argues future dangerousness, and if life without parole is the only alternative to a death sentence, then capital defendants have a right to a jury instruction that the defendant will be sentenced to life without parole if not sentenced to death. ${ }^{196}$ Three years later, the Court held that Simmons announced a new procedural rule not retroactively applicable to convictions that had become final before its announcement. ${ }^{197}$ The Court's holding in Caldwell v. Mississippi - that the Eighth Amendment prohibits imposing the death penalty when the jury is led to believe that it is not responsible for the ultimate decision because an appellate court would review the sentence for correctness ${ }^{198}$ - faced a similar fate. Despite the fact that the Caldwell rule was intended to "enhance[] . . the accuracy of capital sentencing," the Court pronounced it a new, non-watershed procedural rule that did not

Commonwealth v. Banks, 29 A.3d 1129, 1131 (Pa. 2011). After a weeklong hearing, a trial judge found Banks incompetent to be executed, and the Pennsylvania Supreme Court adopted those findings. Id.

192 The Court denied certiorari on Banks's direct appeal on October 5, 1987, Banks v. Pennsylvania, 484 U.S. 873, 873-74 (1987), and eight months and one day later, the Court decided Mills.

193 See, e.g., Crawford v. Washington, 541 U.S. 36, 53-54 (2004) (holding that the Confrontation Clause prohibits the admission of out-of-court testimonial statements unless the declarant is unavailable as a witness and the defendant had a prior opportunity to cross-examine); Blakely v. Washington, 542 U.S. 296, 301 (2004) (holding that any fact, other than a prior conviction, sufficient to increase punishment beyond the state sentencing guidelines' maximum must be proven to a jury beyond a reasonable doubt); Ring v. Arizona, 536 U.S. 584, 589 (2002) (holding that any fact required to impose a death sentence must be proven beyond a reasonable doubt to a jury).

194536 U.S. at $589,597$.

195 Schriro v. Summerlin, 542 U.S. 348, 358 (2004). Perhaps the most controversial part of Schriro was its conclusion that Ring announced a new rule, even though Apprendi v. New Jersey, 530 U.S. 466 (2000), largely had dictated the Court's Ring conclusion. See, e.g., Katharine A. Ferguson, Note, The Clash of Ring v. Arizona and Teague v. Lane: An Illustration of the Inapplicability of Modern Habeas Retroactivity Jurisprudence in the Capital Sentencing Context, 85 B.U. L. REV. 1017, 1036 (2005); Marc E. Johnson, Note, Everything Old Is New Again: Justice Scalia's Activist Originalism in Schriro v. Summerlin, 95 J. CRim. L. \& CRiminology 763, 799-800 (2005).

196512 U.S. 154, 161-62 (1994) (plurality opinion).

197 O'Dell v. Netherland, 521 U.S. 151, 166-67 (1997)

198472 U.S. 320, 328-29 (1985). 
apply retroactively. ${ }^{199}$ As a result, capital habeas applicants whose sentencing proceedings violated the Constitution under Caldwell have no remedy for that constitutional error. ${ }^{200}$

To be sure, the criticism that Teague unfairly treats defendants differently based only on the relatively random date on which their convictions become final may carry little weight with those who view habeas only as a mechanism to ensure the state provides adequate process for correcting constitutional violations, rather than as a means for correcting all constitutional errors. ${ }^{201}$ But limiting habeas only to ensuring adequate state processes is completely inconsistent with the historical equitable nature of the habeas remedy. After all, as Professor Halliday's careful history of habeas demonstrates, the remedy was designed to hear the "sighs" of all prisoners. ${ }^{202}$ And of greater concern, the Teague rule-a rule that clearly has an impact on many of the most serious cases - is not grounded in the equitable principles that guide the other gatekeeping bars. So we turn now to the Teague rule's incompatibility with equity.

\section{The Anomalous and Inequitable Nature of the Teague Rule}

Unlike the other bars on habeas relief, the Teague retroactivity rule cannot be justified on equitable grounds. None of the traditional equity defenses - availability of relief at law, unclean hands, laches, or estoppeleven arguably correlate with the Teague doctrine. In addition, in contrast to the other four gatekeeping doctrines, the applicant's conduct has no bearing on the application of the retroactivity bar. ${ }^{203}$ For instance, an applicant who has diligently presented his claim to the state court and timely filed his petition in federal court still cannot obtain relief for any claim that requires

\footnotetext{
199 Sawyer v. Smith, 497 U.S. 227, 244-45 (1990).

200 The Teague retroactivity bar does not focus on whether the state violated the applicant's constitutional rights but instead whether "a violation of the right that occurred prior to the announcement of the new rule will entitle a criminal defendant to the relief sought." Danforth v. Minnesota, 552 U.S. 264, 271 (2008). In other words, the Teague bar relates to the absence of a remedy, not the absence of a right. See id. at 291 ("A decision by this Court that a new rule does not apply retroactively under Teague does not imply that there was no right and thus no violation of that right at the time of trial — only that no remedy will be provided in federal habeas courts."). This is so because the source of new constitutional rules is the Constitution itself, not any inherent power of the Court to create new rules. "Accordingly, the underlying right necessarily pre-exists our articulation of the new rule." Id. at 271.

201 Professor Paul Bator is probably the best known advocate of the state process view. See, e.g., Paul M. Bator, Finality in Criminal Law and Federal Habeas Corpus for State Prisoners, 76 HARV. L. REV. 441 (1963). Many have studied the conflict between these two views of habeas. See, e.g., Ann Woolhandler, Demodeling Habeas, 45 STAN. L. REV. 575, 577 (1993) (discussing the two competing models of habeas corpus review: the "full-review" model under which courts should fully review any properly preserved constitutional claims and the "institutional competence" model restricting habeas review where the applicant had a " full and fair' opportunity" to present claims in state court).

${ }^{202}$ HALLIDAY, supra note 22, at 7.

203 See supra Part II.B.
} 
any extension of the Supreme Court's federal constitutional procedural rules. He has not unreasonably delayed, he has no remedy under the state court system, and he has raised the argument at every reasonably available opportunity. Put simply, retroactivity falls completely outside both the equitable defenses and the equitable justifications that underlie the other four procedural bars. ${ }^{204}$

Unlike the four habeas bars discussed above, moreover, the Teague rule has no individualized exception. ${ }^{205}$ As discussed above, ${ }^{206}$ the Court in Teague recognized only two "exceptions," neither of which gives individualized consideration to the claim presented. The first-permitting retroactive application of substantive rules - has nothing to do with differentiating claims based upon equitable considerations such as the applicant's conduct. Indeed, the specialized treatment of substantive rulings is not an exception - much less an equitable exception - to the Teague rule at all. As the Court itself has recognized: "[Although this Court has] sometimes referred to [substantive] rules ... as falling under an exception to Teague's bar on retroactive application of procedural rules, they are more accurately characterized as substantive rules not subject to the bar." ${ }^{207}$ The broader point is that neither the Teague rule nor its substantive rule "exception" has anything to do with equitable consideration of the applicant's own delay, forfeiture of claims, or repetitive use of the writ. Teague involves only a technical decision about whether a new rule is "procedural" or "substantive." 208 Such a categorization has nothing whatsoever to do with the applicant's conduct and the equities to which that conduct gives rise.

Nor does the second Teague "exception"-for watershed rules of criminal procedure-provide individualized consideration. Indeed the Court not only applies it categorically for each new rule, with no consideration of the merits of individual claims, but the Court has never found a rule that meets its criteria. In order to decide whether a new rule is

\footnotetext{
204 The Court has justified its Teague rule by invoking other equitable considerations such as judicial economy, but it has never claimed that its rule falls within any of the traditional equitable defenses. See supra Part III.A.

205 The one individualized exception that might apply provides relief if the applicant can demonstrate that "a constitutional violation has probably resulted in the conviction of one who is actually innocent." Murray v. Carrier, 477 U.S. 478, 496 (1986); accord Sawyer v. Whitley, 505 U.S. 333, 339-40 (1992). As discussed above, however, this exception provides relief to virtually (or perhaps actually) no applicants. See supra note 118 and accompanying text. The Court, moreover, has never recognized it as an exception to the Teague bar. Neal Kumar Katyal, Judges as Advicegivers, 50 STAN. L. REV. 1709, 1787 n.376 (1998) (hypothesizing a reason the Court might decide to apply the exception to Teague in the future).

206 See supra Part III.A.

207 Schriro v. Summerlin, 542 U.S. 348, 352 n.4 (2004) (citation omitted). Indeed, if substantive rules are an "exception" to the Teague bar, so too would be relying on cases that did not announce a "new" rule.

208 See supra Part III.A.
} 
"watershed," the Court does consider whether the rule is "necessary to prevent an impermissibly large risk of an inaccurate conviction," 209 but the Court has been clear that the fact that a particular new rule enhances the accuracy of the proceedings or might enhance accuracy in a particular case does not suffice. ${ }^{210}$ Instead, a qualifying rule must be necessary to prevent "an impermissibly large risk of an inaccurate conviction" 211 in general-as opposed to serving to prevent an inaccurate conviction in an individual case. Thus, far from creating an individualized exception to the Teague rule based upon the applicant's behavior or the strength of his claim, the watershed rule exception constitutes only a generalized judgment regarding the fundamental nature of the rule. As discussed above, moreover, the Court has expressed great skepticism that a new rule could ever be "watershed," calling into question whether this creates an exception at all. ${ }^{212}$ Thus, neither the Teague rule nor either of its "exceptions" is marked by any of the equitable characteristics that animate the other gatekeeping habeas requirements.

\section{EQUITY AND NONRETROACTIVITY REVISITED}

What should be done about the equitable outlier status of the Teague nonretroactivity rule? The Supreme Court could, of course, overrule Teague and eliminate the retroactivity bar, thereby bringing habeas doctrine back in line with its equitable origins. But to state it mildly, the chance of the Court doing that ranges from exceedingly slim to none. Although Teague has been the subject of excoriating criticism since

\footnotetext{
209 Whorton v. Bockting, 549 U.S. 406, 418 (2007) (internal quotation marks omitted). To qualify as a watershed rule of criminal procedure, the rule also "must alter our understanding of the bedrock procedural elements essential to the fairness of a proceeding." Id. (internal quotation marks omitted).

${ }^{210}$ See, e.g., Beard v. Banks, 542 U.S. 406, 419-20 (2004) (internal quotation marks omitted) ("But because [a]11 of our Eighth Amendment jurisprudence concerning capital sentencing is directed toward the enhancement of reliability and accuracy in some sense, the fact that a new rule removes some remote possibility of arbitrary infliction of the death sentence does not suffice to bring it within Teague's second exception." (alteration in original)).

211 Whorton, 549 U.S. at 418; see, e.g., id. at 419-20 (comparing the rules of Crawford v. Washington, 541 U.S. 36, 53-54 (2004), and Gideon v. Wainwright, 372 U.S. 335, 342 (1963), to demonstrate why the rule in Crawford does not represent a watershed rule); Schriro, 542 U.S. at 355-56 (reasoning that because the right to a jury trial has been given a "mixed reception" in foreign countries, judicial factfinding is unlikely to so seriously diminish accuracy as to produce an impermissibly large risk of injustice, and the rule of Ring v. Arizona, 536 U.S. 584, 603-09 (2002), requiring jury factfinding, cannot be a watershed rule of procedure).

${ }^{212}$ See Schriro, 542 U.S. at 352 (stating that the class of rules qualifying as watershed rules of criminal procedure is "extremely narrow, and it is unlikely that any ... ha[s] yet to emerge" (alteration and omission in original) (quoting Tyler v. Cain, 533 U.S. 656, 667 n.7 (2001))); Richard H. Fallon, Jr. \& Daniel J. Meltzer, New Law, Non-Retroactivity, and Constitutional Remedies, 104 HARV. L. REV. 1731, 1817 (1991) (criticizing the narrowness of Teague's exceptions); Jason Mazzone, When the Supreme Court Is Not Supreme, 104 Nw. U. L. REV. 979, 1018 (2010) (observing that Gideon is the only rule recognized to date as a watershed rule); supra Part III.A.
} 
immediately after the decision, ${ }^{213}$ none of that criticism appears to have moved the Court in the slightest to overrule it.

The Court could, however, explore a more modest alternative. In keeping with the principles that govern every other habeas gatekeeping doctrine, the Court could ease the rigidity of the Teague rule by permitting equitable exceptions to its operation in individual cases. The Court certainly has the authority to restore equity by fashioning individualized equitable exceptions. Particularly given the Court's recent recognition of the importance of equitable considerations in setting the rules of habeas, this appears to be the perfect opportunity for the Court to consider equitable exceptions to the Teague nonretroactivity rule. ${ }^{214}$ It should exercise its authority to adopt equitable exceptions both because individualized exceptions would mitigate Teague's most inequitable characteristics and because it could do so at little cost to the finality and manageability concerns that the Court has invoked in support of Teague.

\section{A. Restoring Equity}

To introduce equity to the Teague rule, the Court should devise equitable exceptions to the general retroactivity bar that would match the equitable considerations that run through the other gatekeeping bars. The precise content and operation of these exceptions could take a variety of forms and will only be set forth generally below, but three equitable considerations should govern their development. The first should be formulated in keeping with equity's focus on the conduct of the applicant and the exceptions to the other bars that take account of the applicant's conduct. Specifically, the Court should consider the extent to which the applicant has diligently raised the claim in state proceedings even prior to the Court's announcement of the new rule. The second exception should depend on the magnitude of the applicant's interest in the new rule's retroactive application. Finally, in keeping with the equitable tradition of providing a remedy where no other remedy is available, the Court should provide an exception to consider arguments for new rules that can only be

213 See, e.g., Susan Bandes, Taking Justice to Its Logical Extreme: A Comment on Teague v. Lane, 66 S. CAL. L. REv. 2453, 2453 (1993) (describing Teague as a "decision which, on many levels, concerns the failure of judges to take responsibility for their decisions"); Fallon, Jr. \& Meltzer, supra note 212, at 1816 (concluding that "Teague's specific application is both unpersuasive and troubling"); Barry Friedman, Pas De Deux: The Supreme Court and the Habeas Courts, 66 S. CAL. L. Rev. 2467, 2496 \& n.143 (1993) (arguing that Teague is "painfully disingenuous" and that, as applied, it is "completely incoherent and a serious waste of time" and ought to be overruled).

${ }^{214}$ See supra note 69 and accompanying text. The source of the Court's resurgent interest in equity may well be attributable to its invocation of equitable principles in the pre-conviction habeas cases that have landed before the Court as a result of the Guantanamo Bay prosecutions. Regardless of the source, the Court has increasingly invoked traditional principles of equity in its post-conviction habeas jurisprudence. $I d$. 
considered on habeas. ${ }^{215}$ An ameliorative doctrine that takes account of these considerations would restore at least a modicum of equity to the Court's retroactivity doctrine.

The one potential barrier to consideration of claims that meet any exception the Court may create is AEDPA's prohibition on granting relief on a claim that the state court adjudicated on the merits unless the state court's adjudication "resulted in a decision that was contrary to, or involved an unreasonable application of, clearly established Federal law, as determined by the Supreme Court of the United States." ${ }^{16}$ The Court has interpreted this statutory provision to mean that the law must have been "clearly established" at the time of the last state court decision on the merits. ${ }^{217}$ It has not, however, decided whether cases that fall within a Teague "exception" should be treated differently, i.e., whether, assuming that a Teague exception applies, the law need only be "clearly established" at the time the federal court considers the habeas application or needs to be clearly established at the time the state court considered the issue. In order for applicants to obtain relief under new rules falling within the proposed exceptions detailed below, the Court should conclude that Greene does not apply to Teague exceptions. For the limited number of cases falling within one of the proposed exceptions, courts instead should assess whether the rule was "clearly established" immediately after the Supreme Court's new ruling.

1. Providing Relief for Blameless Applicants.-Permitting retroactive application of new rules when the applicant's conduct in pursuing his claim has been blameless goes to the core of equity. ${ }^{218}$ In particular, where the applicant has diligently pursued the claim before the state courts and those courts have ruled on the merits of that claim, no fault can be attributed to the applicant. ${ }^{219}$ To be sure, if the state court's

\footnotetext{
215 See Jackson v. Johnson, 217 F.3d 360, 364 (5th Cir. 2000) (recognizing an additional exception to Teague's bar " $[\mathrm{w}]$ hen an alleged constitutional right is susceptible of vindication only on habeas review").

21628 U.S.C. $\S 2254(d)(1)(2006)$.

217 See Greene v. Fisher, 132 S. Ct. 38, 44 n.*, 45 (2011) (holding that under $§ 2254(d)(1)$, the law must have been "clearly established" as of the time the state court issued its ruling). Although in some ways $\S 2254(\mathrm{~d})(1)$ and Teague address a similar issue - namely, the extent to which state courts should have anticipated any new case decided by the Supreme Court- the Court has been quite clear that the inquiries are separate. See id. at 44 ("We have explained that AEDPA did not codify Teague, and that 'the AEDPA and Teague inquiries are distinct."' (quoting Horn v. Banks, 536 U.S. 266, 272 (2002) (per curiam))).

218 See supra Part II.B.

219 To a certain extent, an applicant who seeks habeas relief under a new rule at the first opportunity after the new rule cannot be completely faulted, since he may have had no way of knowing prior to the Court's decision that the rule would change. Even so, the applicant who raised the issue before the state courts in an effort to get relief has a stronger equitable claim than the applicant who did not, because he has done everything in his power to have the claim heard.
} 
consideration of the issue preceded the Supreme Court's announcement of the new constitutional rule, no fault can be attributed to the actions of that court. But the habeas remedy historically has been available in certain situations even if the state court has not acted in a blameworthy way. Perhaps the clearest example is the Court's holding that new constitutional rules apply to all defendants whose convictions were not final prior to the issuance of the Court's decision. ${ }^{220}$ If, for instance, the defendant completed state court proceedings prior to the new rule and the state courts decided the case under then-existing precedent, but the time for seeking certiorari to the Court had not yet run by the time the Court issued the new rule, habeas relief under the new rule would be available to the applicant in spite of the blamelessness of the state courts' rulings. Providing an exception for applicants who have preserved a claim throughout the course of the proceedings would recognize that faultless applicants should not be punished for the happenstance of timing, in contrast to the harsh reality of the Teague rule as it stands.

An example serves to illustrate this point. In Bintz v. Bertrand, ${ }^{221}$ a jury convicted Robert Bintz of murder in 2000 after the State introduced hearsay evidence including two statements challenged on direct appeal: (1) testimony that the defendant's brother, David, had told police that both he and Robert had been at the scene of the murder on the night in question, and (2) testimony from David's trial by Gary Swendby, David's former cellmate, quoting statements that David made to Swendby indicating that Robert played the primary role in the murder. ${ }^{222}$ At trial and on appeal in 2001, Robert Bintz challenged the admissibility of both of these statements on grounds that their admission deprived him of his Sixth Amendment right to confront witnesses against him, since neither David nor Swendby testified at his trial. Both the state trial court and the appellate court denied Bintz's claims, ${ }^{223}$ concluding that admission of the statements did not violate the then-applicable Confrontation rule. ${ }^{224}$ Three years later, while Bintz's federal habeas claim challenging the admissibility of this evidence under the Confrontation Clause was pending, the Supreme Court held in Crawford v. Washington that the Confrontation Clause forbids the admission of "testimonial" statements against the defendant unless he had a prior opportunity to cross-examine the witness. ${ }^{225}$

\footnotetext{
${ }^{220}$ See Griffith v. Kentucky, 479 U.S. 314, 328 (1987) (holding that new constitutional rules apply to all cases not yet final at the time the Court issued the decision setting forth the new constitutional rule).

221403 F.3d 859 (7th Cir. 2005).

${ }^{222} I d$. at 861-62. Swendby had died by the time of Robert Bintz's trial. Id. at 862 .

${ }^{223} \mathrm{Id}$. at 862.

${ }^{224}$ See Ohio v. Roberts, 448 U.S. 56, 66 (1980) (holding that admission of hearsay statements either falling within "firmly rooted" exceptions or demonstrating particularized guarantees of trustworthiness do not violate the Confrontation Clause).

${ }^{225} 541$ U.S. 36, 68 (2004)
} 
The precise definition of "testimonial" under Crawford remains subject to some debate, but it has been clear from the time Crawford was decided that a formal police interview like that between David and the police constitutes a testimonial assertion ${ }^{226}$ and that Swendby's testimony at the trial of Bintz's brother was "testimonial." Indeed, it is difficult to imagine a statement more "testimonial" than a witness's testimony from another criminal trial. ${ }^{227}$

At every step of the process, Robert Bintz raised, preserved, and litigated the claim that admission of these statements violated his rights under the Confrontation Clause. And the state courts addressed the merits of his claims. ${ }^{228}$ As it turns out, the state courts were wrong and Robert Bintz was right - the statements were testimonial and their admission violated his Sixth Amendment right to confront the witnesses against him. But because the Court issued the opinion in Crawford after Bintz's time for seeking certiorari on direct appeal passed, Teague barred any relief. ${ }^{29}$

For an applicant like Bintz, who makes every effort to present a particular claim of constitutional error to the state courts, and who would prevail but for the accident of timing and the Supreme Court's decision to deny his petition and accept a different case on certiorari, it seems not only inconsistent with fundamental notions of equity but also manifestly unfair to deny a remedy. The Court should rectify that unfairness by adopting an equitable exception to Teague's retroactivity bar for claims, presented to state courts prior to the Court's announcement of the new rule, that are meritorious under the new rule.

\section{Formulating an Exception to Correct the Most Significant} Errors.-Just as providing an exception for blameless conduct imports equitable principles into the retroactivity doctrine, so too does providing a remedy where the constitutional error had the most significant impact on the applicant. Indeed, equity courts arose for the very purpose of remedying claims of strong perceived injustices that could not be addressed in courts of law because of the mechanical operation of the rules of those courts. ${ }^{230}$ Of course, there is no way to precisely measure the significance of

\footnotetext{
${ }^{226}$ See id. at 52 ("Statements taken by police officers in the course of interrogations are also testimonial under even a narrow standard.").

227 See Davis v. Washington, 547 U.S. 813, 836-37 (2006) (Thomas, J., concurring in part and dissenting in part) (arguing for a narrower definition of "testimonial" that would cover only formalized materials such as "[a]ffidavits, depositions, and prior testimony").

${ }^{228}$ Bintz, 403 F.3d at 862-63.

229 See id. at 865-67 (analyzing Crawford under the Teague framework and finding that it does not fit under either of the "exceptions").

${ }^{230}$ See Garrard Glenn \& Kenneth Redden, Equity: A Visit to the Founding Fathers, 31 VA. L. REV. 753, 756 (1945) (footnote omitted) ("[According to Blackstone,] [e]quity exists ... for the correction of situations 'wherein the law, by reason of its universality, is deficient.' By 'the law,' Blackstone meant the common law as administered under common law processes...."); Christopher L. McCall, Comment, Equity up in Smoke: Civil RICO, Disgorgement, and United States v. Philip Morris,
} 
harm resulting from constitutional error. But the Supreme Court might fashion such an exception to the Teague rule by balancing factors related to the applicant's claim against the state's interest in finality. These factors should include an assessment of the strength of the applicant's argument that there was error under the new rule, the extent to which that error affected the outcome of the proceedings, and the severity of the resulting penalty. What follows is one possible method for weighing those interests.

As the Court has repeatedly emphasized, the state has an interest in finality in every habeas case. ${ }^{231}$ The Court therefore could create a Teague exception that requires applicants to make a threshold showing that the alleged constitutional error in fact is an error under the new rule, that the error affected the outcome of the proceedings, and that the penalty imposed was serious. Because this is a balancing standard, these factors would fall across a continuum. ${ }^{232}$ So, for instance, if an applicant had a very strong claim that there was constitutional error that affected the outcome of his proceedings, he might be able to establish his interest even if his sentence was ten years, rather than life or death. And an applicant sentenced to death might meet this test even if his claims on the merits are slightly weaker. If the applicant cannot make the threshold showing (and his case does not fall within one of the other exceptions), Teague would preclude retroactive application of the new constitutional rule. If, however, the applicant establishes these factors, the presumption would be that his claim falls within the equitable exception, and the new rule applies unless the state has an additional interest in nonretroactivity (besides finality and comity) that outweighs the applicant's interest.

The first factor - the strength of the applicant's argument that there was error under the new rule-would require the federal habeas court to evaluate the merits of his claim, imposing some burden on the court. But

74 FORDHAM L. REV. 2461, 2472-73 (2006) (noting that courts of chancery were created because "many meritorious claims were barred from proceeding by the rigidity of the law courts," which limited relief to very specific categories of cases); $c f$. Murray v. Carrier, 477 U.S. 478, 495-96 (1986) (noting that, in extraordinary cases, courts may hear and grant a habeas claim despite an applicable limitation and without a showing of cause and prejudice, when they can determine that a constitutional violation probably has resulted in the conviction of someone who is actually innocent).

231 See, e.g., Danforth v. Minnesota, 552 U.S. 264, 291 (2008) ("It is fully consistent with a government of laws to recognize that the finality of a judgment may bar relief."); Beard v. Banks, 542 U.S. 406, 413 (2004) ("[T]he Teague principle protects not only the reasonable judgments of state courts but also the States' interest in finality quite apart from their courts."); Sawyer v. Smith, 497 U.S. 227, 234 (1990) ("The principle announced in Teague serves to ensure that gradual developments in the law over which reasonable jurists may disagree are not later used to upset the finality of state convictions valid when entered.”); Teague v. Lane, 489 U.S. 288, 308 (1989) (O’Connor, J., plurality opinion) ("[W]e have recognized that [the] interest[ ] of ... finality must also be considered in determining the proper scope of habeas review.").

${ }^{232}$ See T. Alexander Aleinikoff, Constitutional Law in the Age of Balancing, 96 YALE L.J. 943, 948 (1987) (noting that "ad hoc" balancing, defined as balancing of the interests in a particular case, may accord different weight to interests in different cases). 
this small burden should not preclude this factor. There was a long tradition of equitable courts assessing the strength of claims presented by petitioners, even if the equitable court had no jurisdiction over those claims. ${ }^{233}$ In addition, as a practical matter, federal habeas courts - both district courts and courts of appeals - often assess the merits of the applicant's claim as an alternative basis for their rulings, ${ }^{234}$ so this would not require substantially more work than habeas courts already undertake.

The second factor requires the court to assess the impact of the constitutional error on the outcome of the proceedings. Federal habeas courts have a long history of evaluating the extent to which a particular constitutional error affected the scope of the proceedings. ${ }^{235}$ Given that experience, the Court could easily fashion a standard that would ensure that only the most meritorious claims receive the benefit of retroactivity. For instance, the Court could use the harmless error standard that applies to constitutional error identified on habeas review. This standard precludes relief unless the error "had substantial and injurious effect or influence in determining the jury's verdict." ${ }^{236}$ The precise content of the standard has been the subject of some dispute within the Court, primarily because the Court has offered conflicting opinions regarding whether the standard properly should focus on the jury's verdict and the extent to which the constitutional error affected it, ${ }^{237}$ or on the strength of the other untainted evidence presented at trial and the likelihood that another jury would reach the same conclusion even absent the constitutional error. ${ }^{238}$ This dispute

233 See John Leubsdorf, The Standard for Preliminary Injunctions, 91 HARV. L. REV. 525, 529-30 (1978) (describing how early equity courts "became accustomed to assessing the probable strength of the plaintiff's underlying claim" while still remaining reluctant to approach the merits of the underlying legal claim).

${ }^{234}$ See, e.g., Ayala v. Speckard, 131 F.3d 62, 67-69 (2d Cir. 1997) (en banc) (reaching the issue of whether the Sixth Amendment requires reversal of convictions when the public was denied access to testimony during trial in spite of the fact that applicants were seeking to have the court adopt a new rule).

235 See, e.g., Brecht v. Abrahamson, 507 U.S. 619, 638 (1993) (applying a version of the harmless error standard in habeas claims based on constitutional error); Sawyer v. Whitley, 505 U.S. 333, 335-36 (1992) (requiring a strong showing of "actual innocence" where habeas applicants are procedurally barred from raising their claims and cannot show cause and prejudice); Wainwright v. Sykes, 433 U.S. 72, 87 (1977) (applying the traditional cause and prejudice rule to procedurally defaulted habeas claims).

236 See Brecht, 507 U.S. at 638 (emphasis added) (adopting the harmless error standard articulated in Kotteakos v. United States, 328 U.S. 750, 776 (1946)). This version of the harmless error standard represents a more significant hurdle to applicants than the standard that applies to constitutional error on direct review-which requires a court to set aside the conviction unless it finds the error harmless beyond a reasonable doubt. See, e.g., Chapman v. California, 386 U.S. 18, 24 (1967).

237 See, e.g., Sullivan v. Louisiana, 508 U.S. 275, 279 (1993) (internal quotation marks omitted) (noting that the harmless error analysis should "look[ ] . . to the basis on which the jury actually rested its verdict").

238 See, e.g., Neder v. United States, 527 U.S. 1, 18 (1999) (arguing that this inquiry best balances the interests at stake in habeas cases). 
notwithstanding, the harmless error standard continues to apply in habeas cases, and federal courts have significant experience applying it. ${ }^{239}$

This standard also appears to screen all but the most compelling claims. Indeed, according to one influential study tracking the success rates of federal habeas cases, in only 4 out of 267 capital cases (less than 1.5\%) and 4 out of more than 2000 noncapital cases (less than $0.17 \%$ ) did the district court find the alleged constitutional error not harmless. ${ }^{240}$ Thus, the harmless error standard ensures that relief is reserved for the most significant claims of constitutional error.

The final factor on the applicant's side of the balancing - the penalty imposed-would be relatively straightforward to consider in the analysis. To put it simply, given equivalently strong arguments that constitutional error affected the outcome of proceedings, applicants sentenced to death or life without parole ${ }^{241}$ would be much more likely to obtain retroactive application of a new rule than applicants sentenced to terms of several years. ${ }^{242}$ As others have recognized, it is a far different thing to subject an individual to a death sentence or life imprisonment on legally dubious grounds than to, for example, subject that person to a monetary fine or the loss of a subsidy. ${ }^{243}$ Equity, in short, concerns itself with proportionality. Thus, the more severe the punishment imposed, the stronger the case to temper Teague's otherwise wooden rule. Death penalty cases and those involving significant terms of incarceration already constitute the bulk of the federal habeas docket, ${ }^{244}$ and adopting a penalty-sensitive approach to the balancing therefore likely would not result in significantly increased habeas filings.

239 See, e.g., Fry v. Pliler, 551 U.S. 112, 121-22 (2007) (affirming that the Brecht standard applies to all habeas harmless error cases regardless of whether the lower state court used the traditional "harmless beyond a reasonable doubt" standard); California v. Roy, 519 U.S. 2, 4-5 (1996) (per curiam) (remanding case for lower court to apply the Brecht standard and emphasizing that it applies to all habeas claims related to "trial errors"); O’Neal v. McAninch, 513 U.S. 432, 436 (1995) (applying the Brecht harmless error standard and finding that when a judge "is in grave doubt" as to whether it is met, "that error is not harmless").

240 KING ET AL., supra note 17, at 50, 52. The study tracked only explicit findings that an error was not harmless, not cases concluding that the error was harmless. Id. at 63.

241 Thomas H. Cohen \& Tracey Kyckelhahn, Bulletin: Felony DeFendants in Large URBAN COUNTIES, 2006, at 12-13 (2010), available at http://www.bjs.gov/content/pub/pdf/fdluc06.pdf (presenting data about sentencing patterns for persons convicted of various felonies).

242 The Court has repeatedly recognized that "death is different." See Harmelin v. Michigan, 501 U.S. 957, 994-95 (1991) (upholding mandatory sentences of life imprisonment even though the Eighth Amendment requires discretion in death cases).

243 See Michael Coenen, Of Speech and Sanctions: Toward a Penalty-Sensitive Approach to the First Amendment, 112 COLUM. L. REV 991, 999-1000 (2012) (noting the importance of severity of the penalty for purposes of determining First Amendment violations).

244 KING ET AL., supra note 17, at 19-20 (noting in a study of federal habeas applicants that, of those noncapital applicants for whom information on sentencing in state court was provided, " $27.7 \%$ were serving life sentences [and o]f the remainder, the average sentence being served was 20 years" and "[o]nly $12 \%$ of those with a term of years were serving five years or less"). 
On the State's side of the balancing, the State always has an interest in ensuring finality of convictions. And that interest would be sufficient to outweigh the applicant's interests if the applicant could not make a sufficient showing on the factors described above. If the court deemed the applicant's claim sufficiently compelling to overcome the State's interest in finality, however, the State then could identify any additional interests specific to the applicant's case, including, for example, that a long period of time elapsed since conviction, making retrial impossible. If the State articulated specific additional interests in finality, the trial court then would have to include those interests in the balance.

An example illustrates the point. Recall Robert Bintz, the defendant against whom the State introduced a number of out-of-court statements, including (1) a confession to law enforcement officers given by his brother, David, and (2) testimony that David's cellmate had given at David's trial. ${ }^{245}$ As discussed above, Bintz had a strong claim that Crawford v. Washington would have prohibited admission of these two statements if it had applied. ${ }^{246}$ And he was sentenced to life in prison as a result of his conviction. ${ }^{247}$ Two of the three factors - the strength of Bintz's claim and the magnitude of the penalty - therefore weigh strongly in favor of retroactive application of Crawford. The last factor is subject to more argument. After all, the disputed testimony, from the mouth of his brother, arguably provided significantly damning evidence against Bintz. On the other hand, the disputed evidence arguably was cumulative. ${ }^{248}$ But the other two factors arguably would have outweighed the strength of the evidence. Bintz therefore would have had a strong case that he met a threshold showing necessary for retroactive application of Crawford.

The State might, of course, have had significant arguments against retroactivity. In particular, although less than a year and a half passed between the time Bintz's conviction became final and the Court's decision in Crawford, the time between the conviction and habeas petition was relatively significant, which gave the State an argument that it had a significant interest in finality. That fact notwithstanding, Bintz likely had a strong argument that he was entitled to retroactive application of Crawford under this standard.

\footnotetext{
245 See supra notes 221-22 and accompanying text.

${ }^{246}$ See supra notes 225-29 and accompanying text. The Government's best argument that Swendby's testimony was admissible probably would be that Swendby testified at Bintz's preliminary hearing, so Bintz presumably had at least some opportunity to cross-examine him then. See Bintz v. Bertrand, 403 F.3d 859, 862 (7th Cir. 2005) (noting that a joint preliminary hearing was held).

${ }^{247}$ See State v. Bintz, 650 N.W.2d 913, 915 (Wis. Ct. App. 2002), abrogated by Crawford v. Washington, 541 U.S. 36 (2004).

248 See Bintz, 403 F.3d at 869 (holding that even if admission of either of the statements was constitutional error, it would be harmless because other evidence corroborated it). The admission of at least some of that other evidence arguably violated Bintz's Confrontation Clause rights, but the Court held that Bintz procedurally defaulted those claims. Id. at 863-64.
} 
Under this proposed standard, there will, of course, be many cases where the applicant has only a weak claim of constitutional error under the new rule, and the argument for retroactive application therefore will fail with little effort by the courts. And there also will be cases in which the applicant has little to no argument that error under the new rule affected the outcome of his case, and the courts can easily conclude that the new rule does not apply retroactively.

Admittedly, this standard will also give rise to more difficult questions. Beard v. Banks ${ }^{249}$ represents just such a case. Recall that Banks, sentenced to death, argued that he would not have been sentenced to death if a new constitutional rule-holding that the state cannot require unanimity as to mitigating factors ${ }^{250}$ - had applied to his case. ${ }^{251}$ Banks certainly convinced the Third Circuit that the jury instructions and verdict form used in his case violated the rule announced in Mills. ${ }^{252}$ But the State had a strong argument that nothing in the proceedings violated the rule announced in Mills and that even if it did, the jury's verdict was not affected by that error. And of course, Banks was a capital case, further raising the stakes. Cases like Banks would require significant thought and effort by the courts to assess the applicant's (and the State's) interests in retroactivity or nonretroactivity, and it is not at all clear whether Banks would qualify for the proposed exception. But it is fair to say that such effort is justified in cases involving the most significant penalties, and, in fact, the courts in Banks appear to have devoted significant time and thought to the case, even in the absence of a Teague exception. In short, this exception may require some work on the part of federal habeas courts, but that effort ensures that applicants get individual consideration of their claims and ultimately that habeas remains true to its equitable origins.

3. The "No-Forum" Exception.-Finally, the Supreme Court should adopt an exception to Teague's nonretroactivity rule so that federal habeas courts can consider arguments for new federal constitutional rules that cannot (and could never) be decided in any other forum. Such an exception would reflect the extraordinary nature of the equitable remedy of the writ of habeas corpus and the fact that it was designed to remediate errors for which there are no other remedies. ${ }^{253}$

Teague effectively prohibits the Court from even considering whether to adopt a new procedural rule in a habeas case. The Court cannot announce such a rule in a habeas case, no matter how well-preserved and

249542 U.S. 406 (2004).

250 Mills v. Maryland, 486 U.S. 367, 384 (1988).

251 See supra notes 176-92 and accompanying text.

252 See Banks v. Horn, 271 F.3d 527, 551 (3d Cir. 2001).

253 See supra note 72 (listing cases describing the extraordinary nature of the remedy); supra note 230 (identifying sources documenting the history of the courts of equity as providing remedies to those who had no remedy at law). 
important the issue, unless it falls within the "watershed rule" exception ${ }^{254}$ - an exception, as articulated above, that the Court has never used. ${ }^{255}$ Teague therefore effectively prohibits the Court from adopting any new procedural rule that would apply only in habeas proceedings.

Again, an example illustrates the problem. As the law stands, Teague prevents any federal court from deciding that state habeas applicants (or any category of them) have a right to counsel in those proceedings. The Court held in Coleman v. Thompson that there generally is no right to counsel in state post-conviction habeas proceedings. ${ }^{256}$ It left open, however, the question of whether states must appoint counsel in "collateral proceedings which provide the first occasion to raise a claim of ineffective assistance at trial" (so-called "initial-review collateral proceedings") ${ }^{257}$ and whether capital habeas defendants have a right to counsel in their first collateral proceeding (although it has strongly indicated that they do not). ${ }^{258}$ If the Court wanted to revisit the right to counsel in initial-review collateral proceedings or capital defendants' right to counsel for first habeas proceedings, it does not appear that the Court could reach either issue in any proceeding. After all, any rule providing such a right would be a new rule and thus would be barred by Teague. ${ }^{259}$ And because the claimed right by its nature would apply only on collateral review, defendants on direct review would lack standing to raise this issue. ${ }^{260}$ Thus, because the conviction of any applicant raising such a claim already would be final (and the claim therefore Teague-barred), the result would be that no

254 See Teague v. Lane, 489 U.S. 288, 316 (1989) (O’Connor, J., plurality opinion) (“[H]abeas corpus cannot be used as a vehicle to create new constitutional rules of criminal procedure unless those rules would be applied retroactively to all defendants on collateral review through [the watershed rule exception] we have articulated."); see also Yale L. Rosenberg, Kaddish for Federal Habeas Corpus, 59 GEO. WASH. L. REV. 362, 366-67 (1991) (surmising that Teague's watershed rule exception "is arguably not an exception at all" and that because of its confluence with the threshold nature of the retroactivity inquiry, "federal habeas corpus would henceforth generally be available only to vindicate constitutional rights already clearly in existence").

${ }^{255}$ See supra Part III.A.

256501 U.S. 722, 752 (1991); accord Pennsylvania v. Finley, 481 U.S. 551, 555 (1987).

257 Martinez v. Ryan, 132 S. Ct. 1309, 1315 (2012).

258 See Murray v. Giarratano, 492 U.S. 1, 10 (1989) (plurality opinion) (concluding, in 42 U.S.C. $\S 1983$ action, that "meaningful access to the courts" requirements, set forth in Bounds v. Smith, 430 U.S. 817 (1977), do not require appointment of counsel in capital cases because the Finley rule "should apply no differently in capital cases than in noncapital cases"); id. at 14-15 (Kennedy, J., concurring in the judgment) (suggesting that the Constitution does not require states to provide counsel to all capital defendants on habeas review).

259 See Teague, 489 U.S. at 301 (O’Connor, J., plurality opinion) (“'[A] case announces a new rule when it breaks new ground or imposes a new obligation on the States or the Federal Government.... [A] case announces a new rule if the result was not dictated by precedent existing at the time defendant's conviction became final.").

${ }^{260}$ See, e.g., Kowalski v. Tesmer, 543 U.S. 125, 130-34 (2004) (denying claim by attorneys based on hypothetical future arguments because of an absence of general and third-party standing). 
defendant —and, in particular, no habeas applicant—could bring the issue before the Court. ${ }^{261}$

In this way, Teague has fundamentally altered the Court's institutional role as the final arbiter of federal constitutional rights by restricting the Court's ability to reach, in any case, issues related to applicants' federal constitutional rights. This is so because Teague not only prevents the Court from reaching the issue in a federal habeas proceeding, but also precludes the Court from reaching the issue on certiorari from a state habeas proceeding. If, for example, an applicant seeks state (rather than federal) habeas relief, arguing that the federal Constitution gives capital defendants a right to counsel in first habeas proceedings, the state court conclusion that there is no such right cannot be challenged either on direct review to the Supreme Court or by way of federal habeas. The difficulty is that such a claim arises only in collateral proceedings, and Teague therefore forecloses any consideration of the state court's ruling that would produce a "new rule."

As a practical matter, the Teague-barred claims in this category will relate to a limited category of cases: (1) right to counsel in certain types of collateral proceedings, (2) ineffective assistance of counsel at stages of direct review that result in a denial of certiorari (and thus a final conviction), ${ }^{262}$ (3) constitutional claims related to the Court's certiorari process on direct review, or (4) other constitutional rights of applicants either on state or federal habeas. The absence of any forum to consider these issues, and the concomitant absence of any mechanism for the Court ever to do so, argues in favor of the creation of an exception for this category of cases.

\footnotetext{
261 The Court recently confronted this issue regarding the right to counsel on initial-review collateral proceedings. Martinez, 132 S. Ct. at 1319. As discussed supra Part II.C, the Court in Martinez refused to decide whether applicants have such a constitutional right, instead holding that as an equitable matter, the failure to appoint counsel in those proceedings could constitute cause to excuse procedural default. See supra notes 114-15 and accompanying text. And given the Teague rule, it does not appear that the Court could have reached the constitutional issue. See Respondent's Brief on the Merits at 36-41, Martinez, 132 S. Ct. 1309 (No. 10-1001), 2011 WL 3947554, at *36-41. Of course, the Court's holding may open the door for the Court to reach the constitutional issue. There now would be a much stronger argument that any determination of the constitutional right to counsel in these proceedings would not be a "new rule." But the combination of the Court's broad definition of "new rules" and its express reservation of the issue in Martinez still might mean that this would constitute a new rule, in which case habeas applicants could not use it unless they could successfully argue that it represents a "watershed rule."

262 The Court has never recognized a right to counsel, and therefore the right to the effective assistance of counsel, at any "discretionary" stage, which includes petitions for certiorari to the highest state court or the Supreme Court. See, e.g., Wainwright v. Torna, 455 U.S. 586, 587-88 (1982) (per curiam) (rejecting the applicant's habeas claim that his counsel was ineffective in filing his petition for certiorari because he had no constitutional right to counsel at the certiorari filing stage, so "he could not be deprived of the effective assistance of counsel" at that time (citing Ross v. Moffitt, 417 U.S. 600, 610 (1974) (rejecting the argument for a right to counsel beyond the direct appeal of right))).
} 
Indeed, a court addressing one of those claims developed just such an exception. In Jackson v. Johnson, the applicant sought to raise an ineffective assistance of counsel claim on the grounds that his counsel on direct state appeal failed to file a timely motion for rehearing. ${ }^{263}$ The Fifth Circuit acknowledged that Jackson sought to have the court decide a new constitutional rule with respect to the reach of ineffective assistance claims. ${ }^{264}$ But it also recognized that "the constitutional question presented ... could be raised only on collateral review," and it therefore found itself "obliged to give serious consideration to the merits of [the] claim," Teague's bar notwithstanding ${ }^{265}$ Following the lead of the Fifth Circuit in Jackson, the Supreme Court should create an exception to Teague so that this type of issue can be considered. Indeed, in Jackson v. Johnson, the claim for an equitable exception to Teague is particularly compelling because without one, there would be no adequate remedy anywhere for the allegedly wronged applicant.

\section{B. The Costs of Equity}

The argument that the Supreme Court should adopt equity-based exceptions to the Teague nonretroactivity rule might raise concerns about state interests in finality and, especially, judicial efficiency. Although the Court emphasized finality interests in Teague, ${ }^{266}$ concerns about its own caseload may have been more urgent. After all, decisions like Blakely $v$. Washington, holding unconstitutional sentencing under guidelines systems that permit enhanced sentences based on judicial findings of fact by a preponderance of the evidence, ${ }^{267}$ affect a huge number of cases. ${ }^{268}$ Indeed, the Blakely dissent warned that the Court's holding, even if applied only prospectively, "threatens an untold number of criminal judgments." 269 The prospect of thousands of additional cases stemming from applying similar

263217 F.3d 360, 361 (5th Cir. 2000).

264 Id. at 363-64.

265 Id. at 364.

266 Teague v. Lane, 489 U.S. 288, 308-10 (1989) (O’Connor, J., plurality opinion).

267 See 542 U.S. 296, 305 (2004).

268 See Jon Wool \& Don Stemen, Aggravated Sentencing: Blakely v. Washington: Practical Implications for State Sentencing Systems, POL'Y \& PRAC. REV., Aug. 2004, at 1, 2-6 (noting that Blakely's rule "fundamentally affect[s]" systems in at least thirteen states); Isaac M. Gradman, Note, Hot Under the White Collar: What the Rollercoaster in Sentencing Law from Blakely to Booker Will Mean to Corporate Offenders, 1 N.Y.U. J.L. \& BUS. 731, 740 (2005) ("Thousands of defendants were potentially affected by Blakely and its aftershocks.").

269 Blakely, 542 U.S. at 323, $324 \mathrm{n} .2$ (O'Connor, J., dissenting) (noting that, in the federal system alone, "[o]n March 31, 2004, there were 8,320 federal criminal appeals pending in which the defendant's sentence was at issue"). 
rulings retroactively may cause the Court sleepless nights and thus help reinforce Teague. ${ }^{270}$

This concern is overblown for several reasons. First, the Court does not create a significant number of new constitutional procedure rules. Second, even absent Teague's retroactivity bar, federal habeas claims still would be subject to the limitations discussed above-abuse of the writ, exhaustion, the statute of limitations, and procedural default ${ }^{271}$ - as well as the very deferential standard of review set forth in AEDPA, ${ }^{272}$ all of which impose significant obstacles to relief. ${ }^{273}$ Third, most of the Court's new rules would not affect a significant number of cases. For instance, new rules related to trial rights would not apply to the $95 \%$ of convictions in felony cases that result from guilty pleas. ${ }^{274}$ Similarly, because the Fourth Amendment's exclusionary rule does not apply to habeas cases wholly apart from Teague, ${ }^{275}$ new Fourth Amendment rules would continue not to threaten interests in comity, federalism, and finality. Of particular importance, making retroactive the Court's death penalty jurisprudence would result in very few additional habeas cases, both because of the infrequency of capital sentences ${ }^{276}$ and because capital defendants very likely will file federal habeas applications regardless of whether new rules

${ }^{270}$ The Court has not yet decided whether Blakely applies retroactively. See, e.g., Burton v. Stewart, 549 U.S. 147, 149 (2007) (per curiam) (not addressing the question because the petitioner had not complied with the statutory gatekeeping requirements). It has held that Ring v. Arizona, 536 U.S. 584 (2002), also a sentencing-focused rule, does not apply retroactively. Schriro v. Summerlin, 542 U.S. 348, 351-55, 358 (2004). Because the Arizona capital punishment scheme at issue in Ring required proof of factors leading to death eligibility beyond a reasonable doubt, Ring, 536 U.S. at 597, however, Summerlin does not necessarily dispose of the Blakely retroactivity question. See Stephanos Bibas, Blakely's Federal Aftermath, 16 FED. SENT'G REP. 333, 337 (2004).

271 Both the statute of limitations and the statutory abuse of the writ doctrine have exceptions if the claim relies on "a new rule of constitutional law, made retroactive to cases on collateral review by the Supreme Court, that was previously unavailable ..." 28 U.S.C. $§ 2244(b)(2)(A),(d)(1)(C)(2006)$. As a result, these doctrines may not provide significant barriers to retroactive claims. Nonetheless, the procedural default doctrine likely would preclude relief in many cases even if the Court made the new rule retroactive.

${ }^{272} I d . \S 2254(\mathrm{~d})$.

273 Cf. Blume, AEDPA: The "Hype" and the "Bite," supra note 141, at 297 (concluding that AEDPA has had less impact than people had predicted, in large part because the Court already had significantly limited the habeas remedy).

274 See, e.g., Crawford v. Washington, 541 U.S. 36, 53-54 (2004) (holding that the Confrontation Clause requires face-to-face confrontation to offer "testimonial" statements against defendants); see also COHEN \& KYCKELHAHN, supra note 241 , at 10 (noting that $95 \%$ of convictions in felony cases acquired within one year resulted from guilty pleas).

275 See Stone v. Powell, 428 U.S. 465, 493-95 (1976).

276 Tracy L. Snell, Capital Punishment, 2010-Statistical Tables, BurEAu OF JuST. STAT. Bull., Dec. 2011, at 18, available at http://bjs.ojp.usdoj.gov/content/pub/pdf/cp10st.pdf (reporting a general decline in the number of persons sentenced to death in the United States, down to 104 in 2010, compared with 224 ten years earlier). 
apply retroactively. ${ }^{277}$ Finally, all of these exceptions are quite narrow and therefore do not create a risk that even once-in-a-generation cases like Blakely would overwhelm the federal habeas system. ${ }^{278}$

That leaves, then, only the State's interest in finality. To be sure, permitting exceptions to the Teague bar would allow certain habeas applicants to raise additional claims and might increase the number of applicants as well. But in considering the interests on both sides, rather than only on the State's side, the balance of equities favors retroactive application of new rules in cases that meet these narrow exceptions. As discussed above, ${ }^{279}$ by limiting retroactive application to the most faultless applicants and the strongest or most compelling claims, the number of potential claims drops significantly, thereby reducing the corresponding cost to finality. Limiting retroactive application to those facing the most significant penalties or asserting the strongest claims regarding the accuracy of the results, moreover, protects both the applicant's and society's interests in providing habeas relief. ${ }^{280}$

\section{CONCLUSION}

The writ of habeas corpus fundamentally and historically is an equitable remedy. Operating as an equitable outlier, Teague's retroactivity rule has little justification beyond the general effort to limit availability of the habeas remedy. That effort, however, neither acknowledges the equitable nature of the habeas remedy nor provides an adequate justification for the far-reaching sweep of Teague's rule. The Supreme Court therefore should adopt exceptions to its broad coverage that link the retroactivity bar to equitable norms that inform every other area of habeas law.

277 See James S. Liebman et al., A Broken System: Error Rates in Capital Cases, 1973-1995, at 5-6 (June 12, 2000) (unpublished study), available at $\mathrm{http}: / / \mathrm{www} 2.1$ aw.columbia.edu/instructionnalservices/ liebman/ (finding that $40 \%$ of death judgments reviewed on federal habeas between 1973 and 1995 were set aside); see also Victor E. Flango, State Justice InSt., Habeas Corpus in STATE and FEDERAL COURTS 10 (1994), available at http://cdm16501.contentdm.oclc.org/cdm/ref/collection/ criminal/id/0 (showing a general uptick in the number of federal habeas petitions filed by state prisoners between 1941 and 1991).

278 The other rule that arguably affects as many cases as Blakely is the Court's holding in Padilla v. Kentucky that failure to inform a defendant of deportation consequences could constitute ineffective assistance of counsel. 130 S. Ct. 1473, 1483-84 (2010). The Court recently accepted certiorari to determine whether Padilla constitutes a "new rule" for Teague purposes. See Chaidez v. United States, 655 F.3d 684, 694 (7th Cir. 2011), cert. granted, 132 S. Ct. 2101 (2012).

279 See supra Part IV.A.

280 See, e.g., State v. Whitfield, 107 S.W.3d 253, 266-68 (Mo. 2003) (en banc) (refusing to apply Teague and holding that Ring v. Arizona, 536 U.S. 584 (2002), applied retroactively to capital cases in state habeas proceedings because the right to jury trial is a "fundamental right" and because only five cases were affected by its holding). The relief in Whitfield was granted on a motion to recall the mandate, but the court made clear that the habeas remedy also would have been available. $I d$. at 269 n.19. 